Keywords: Sludge, DWPF, CPC

Retention: Permanent

\title{
High Sodium Simulant Testing to Support SB8 Sludge Preparation
}

J.D. Newell

September 2012

Savannah River National Laboratory Savannah River Nuclear Solutions, LLC Aiken, SC 29808

Prepared for the U.S. Department of Energy under contract number DE-AC09-08SR22470. 
SRNL-STI-2012-00452

Revision 0

\section{DISCLAIMER}

This work was prepared under an agreement with and funded by the U.S. Government. Neither the U.S. Government or its employees, nor any of its contractors, subcontractors or their employees, makes any express or implied:

1. warranty or assumes any legal liability for the accuracy, completeness, or for the use or results of such use of any information, product, or process disclosed; or

2. representation that such use or results of such use would not infringe privately owned rights; or

3. endorsement or recommendation of any specifically identified commercial product, process, or service.

Any views and opinions of authors expressed in this work do not necessarily state or reflect those of the United States Government, or its contractors, or subcontractors.

\section{Printed in the United States of America \\ Prepared for \\ U.S. Department of Energy}




\section{REVIEWS AND APPROVALS}

AUTHORS:

J.D. Newell, Process Technology Programs

Date

TECHNICAL REVIEW:

D.C. Koopman, Process Technology Programs

Date

APPROVAL:

C.C. Herman, Manager

Date

Process Technology Programs

S.L. Marra, Manager

Date

Environmental \& Chemical Process Technology Research Programs

John Occhipinti, Manager

Date

Process Cognizant Engineering, Waste Solidification Engineering 


\section{EXECUTIVE SUMMARY}

Scoping studies were completed for high sodium simulant Sludge Receipt and Adjustment Tank (SRAT) and Slurry Mix Evaporator (SME) cycles to evaluate the impact of reduced washing during Sludge Batch (SB) 8 preparation on the Defense Waste Processing Facility (DWPF) Chemical Process Cell (CPC) processing. Simulants were prepared to the projected Tank 40 supernate composition for cases of $2 \mathrm{M}$ and $2.5 \mathrm{M}$ sodium in Tank 51 after washing. The simulants were $1.6 \mathrm{M}$ and $1.9 \mathrm{M}$ in sodium. Two SRAT/SME cycles were performed with the $1.9 \mathrm{M}$ sodium simulant at $100 \%$ and $130 \%$ of the Koopman Minimum Acid (KMA) stoichiometry. KMA and the Hsu equivalent were within 1\% of each other. Four SRAT/SME cycles were performed with the $1.6 \mathrm{M}$ sodium simulant at $100 \%, 110 \%, 125 \%$, and $130 \%$ of the Koopman Minimum Acid stoichiometry.

Test simulants were prepared from blends of Tank 4, Tank 7, and Tank 12 simulants originally prepared for SB7a and SB7b testing combined with projected SB8 supernate compositions. Mercury and noble metals levels consistent with SB7 were used. These levels were expected to be conservative. The increased sodium hydroxide, carbonate, and nitrite concentrations in the less washed supernates led to increased acid demands per gallon of sludge slurry. The objective of this work was to determine if the resulting increased acid demand would overly constrain the available window of stoichiometric factors that define the region between successful nitrite destruction and excessive hydrogen generation.

Although efforts were made to establish a suitable operating window of at least $30 \%$ per the Koopman and Hsu equation for sludge-only processing, none were considered viable for this particular simulant. Both the $2 \mathrm{M}$ and $2.5 \mathrm{M} 130 \%$ and the $2 \mathrm{M} 125 \%$ acid runs exceeded the DWPF hydrogen limit. Hydrogen generation is driven by noble metal concentration. Processing at these levels of sodium concentrations may be feasible if noble metal concentrations are similar to SB3 levels ${ }^{1}$ (about $50 \%$ of the amount used in these tests). The low acid runs at $100 \%$ failed to destroy nitrite. Only the $2 \mathrm{M} 110 \%$ acid run succeeded at destroying nitrite and not producing excessive hydrogen. A summary of these results is presented in the following table:

Summary of Scoping Study Results

\begin{tabular}{|c|c|c|}
\hline Run ID & Pass/Fail & Constraint \\
\hline $2 \mathrm{M}-100$ & Fail & Nitrite $(3800 \mathrm{mg} / \mathrm{kg})$ \\
\hline $2 \mathrm{M}-110$ & Pass & Nitrite $(620 \mathrm{mg} / \mathrm{kg})$ \\
\hline $2 \mathrm{M}-125$ & Fail & Hydrogen $(\mathrm{SME})$ \\
\hline $2 \mathrm{M}-130$ & Fail & Hydrogen $(\mathrm{SME})$ \\
\hline $2.5 \mathrm{M}-100$ & Fail & Nitrite $(4900 \mathrm{mg} / \mathrm{kg})$ \\
\hline $2.5 \mathrm{M}-130$ & Fail & Hydrogen $(\mathrm{SRAT} / \mathrm{SME})$ \\
\hline
\end{tabular}

The results presented in this report are valid only for the simulant and levels of noble metals tested. SB7 levels of noble metals and mercury were used for this scoping study and represent a maximum bounding scenario. SB8 levels of noble metals are projected to be slightly lower and SB8 mercury concentrations are projected to be slightly higher which could both mitigate some of the hydrogen generation. Recent projections for oxalate are only about half as large as those tested which brings the minimum acid requirement for nitrite destruction closer to the value predicted by the KMA. SB8 also appears to be much higher in Fe/Al ratio than SB7a or SB7b, so the simulant tested in these studies is not a good match in terms of insoluble solids concentration to that expected for SB8. 


\section{TABLE OF CONTENTS}

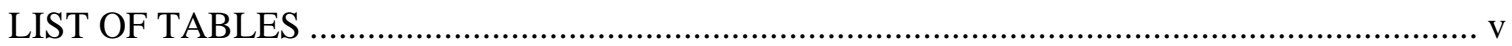

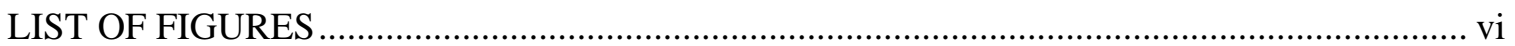

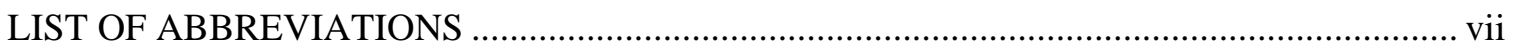

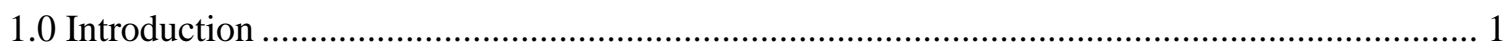

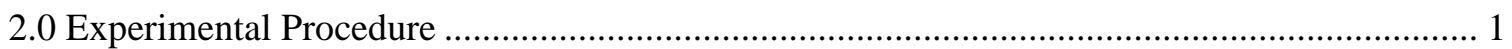

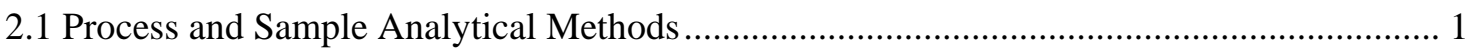

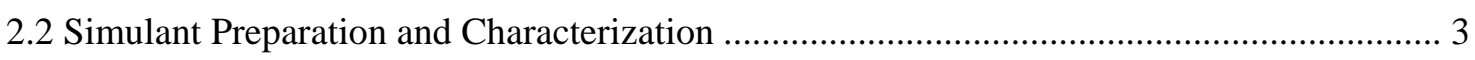

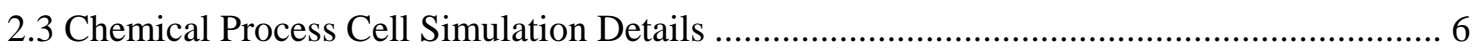

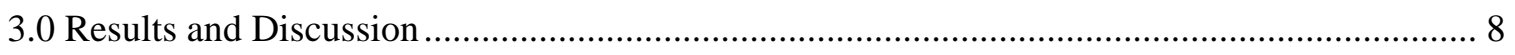

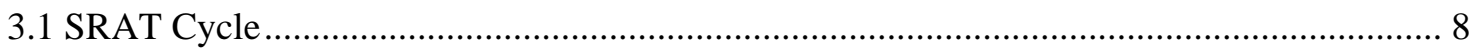

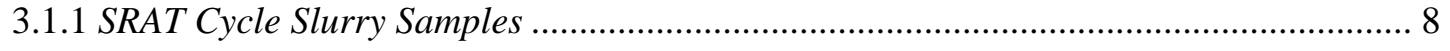

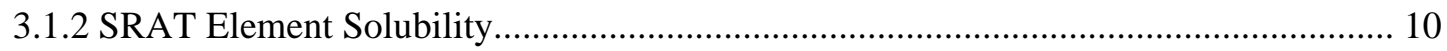

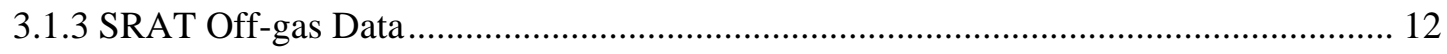

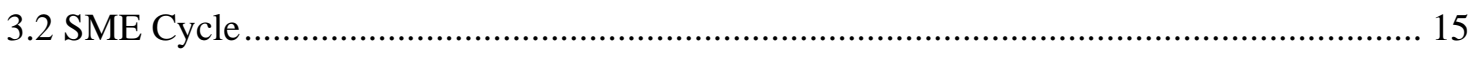

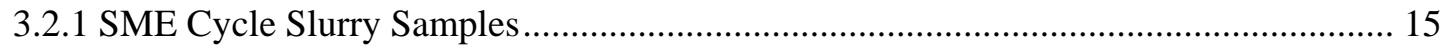

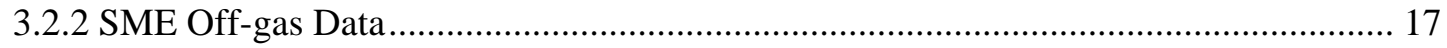

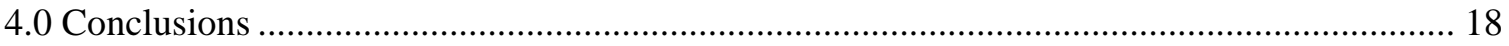

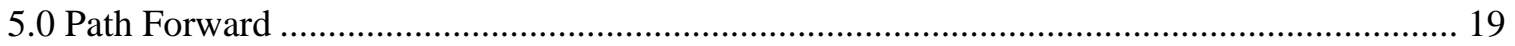

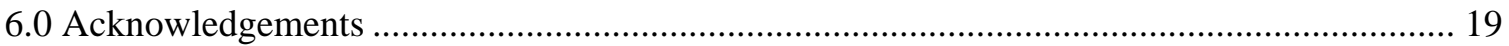

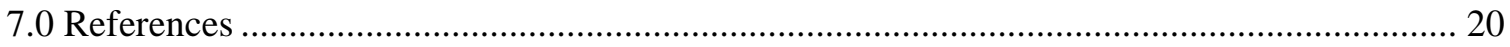

\section{LIST OF TABLES}

Table 1. Mass Spectrometer Calibration Gases............................................................................ 3

Table 2. Elemental composition of SRAT feeds calcined at $1100^{\circ} \mathrm{C}$, wt $\%$................................. 4

Table 3. Simulant and Radioactive Feed Properties .................................................................. 5

Table 4. Noble metal and mercury, wt $\%$ in total solids ............................................................... 5

Table 5. Stoichiometric acid calculation results, moles acid/L trimmed slurry ............................. 7

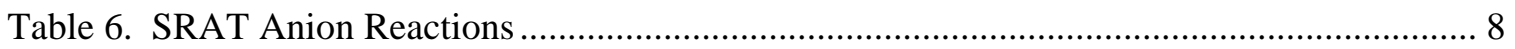

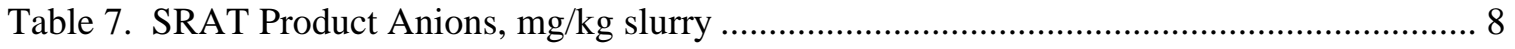

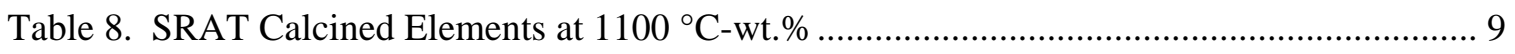

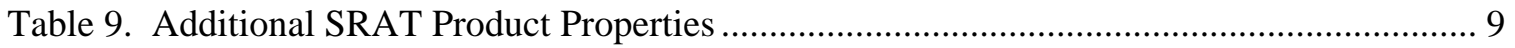


Table 10. Dissolution percent of elements following formic acid............................................ 11

Table 11. Dissolution percent of elements after four hours reflux ............................................. 11

Table 12. Dissolution percent of elements after eight hours reflux........................................... 12

Table 13. Dissolution percent of elements after twelve hours reflux .......................................... 12

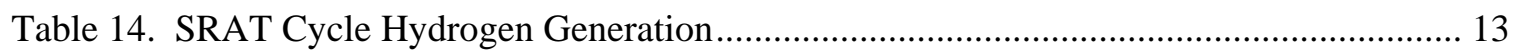

Table 15. SRAT Cycle Carbon Dioxide Generation ................................................................. 14

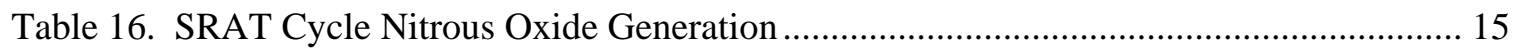

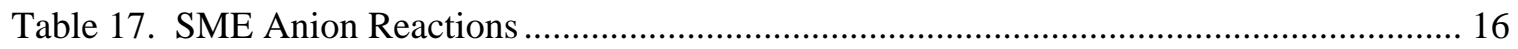

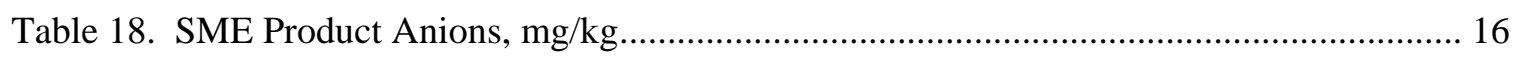

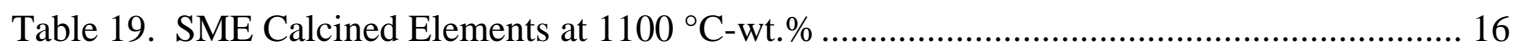

Table 20. Additional SME Product Properties ............................................................................ 17

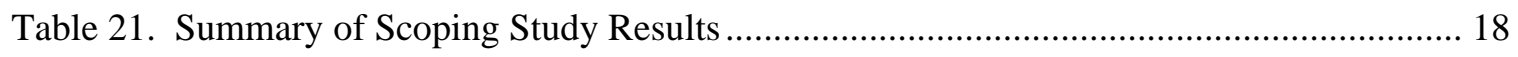

\section{LIST OF FIGURES}

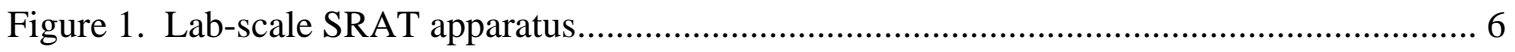

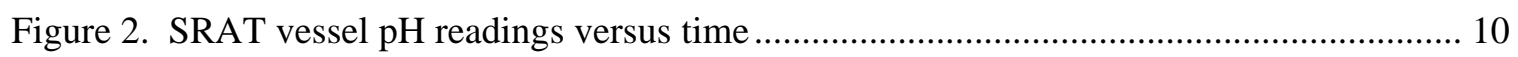

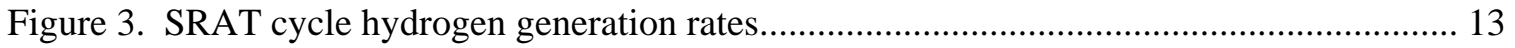

Figure 4. SRAT cycle $\mathrm{CO}_{2}$ during and after acid addition ....................................................... 14

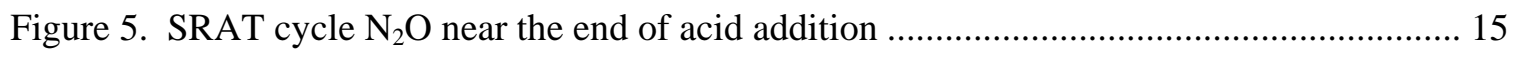

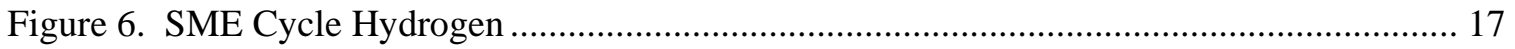

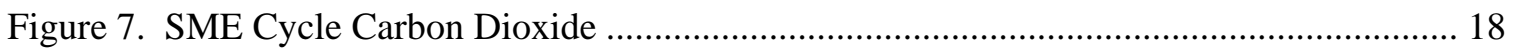




\section{LIST OF ABBREVIATIONS}

$\begin{array}{ll}\text { SRNL } & \text { Savannah River National Laboratory } \\ \text { AD } & \text { Analytical Development } \\ \text { ARP } & \text { Actinide Removal Process } \\ \text { BDL } & \text { Below Detection Limit } \\ \text { CPC } & \text { Chemical Process Cell } \\ \text { CSTR } & \text { Continuously Stirred Tank Reactor } \\ \text { DWPF } & \text { Defense Waste Processing Facility } \\ \text { FAVC } & \text { Formic Acid Vent Collector } \\ \text { FTIR } & \text { Fourier Transform Infrared Spectrometer } \\ \text { GC } & \text { Gas Chromatograph } \\ \text { ICP-AES } & \text { Ion Coupled Plasma - Atomic Emission Spectrometry } \\ \text { KMA } & \text { Koopman Minimum Acid } \\ \text { MS } & \text { Mass Spectrometry } \\ \text { MCU } & \text { Modular Caustic Side Solvent Extraction Unit } \\ \text { MWWT } & \text { Mercury Water Wash Tank } \\ \text { PSAL } & \text { Process Science Analytical Laboratory } \\ \text { PTP } & \text { Process Technology Programs } \\ \text { SB } & \text { Sludge Batch } \\ \text { SME } & \text { Slurry Mix Evaporator } \\ \text { SRAT } & \text { Sludge Receipt and Adjustment Tank } \\ \text { TIC } & \text { Total Inorganic Carbon } \\ \text { TTQAP } & \text { Task Technical and Quality Assurance } \\ \text { TTR } & \text { Technical Task Request } \\ \text { WL } & \text { Waste Loading }\end{array}$




\subsection{Introduction}

The Defense Waste Processing Facility (DWPF) Chemical Process Cell (CPC) process was developed based on well washed sludges with supernate sodium contents of approximately $0.5 \mathrm{M}$. Starting with Sludge Batch 3 (SB3), less washing was performed during sludge preparation and sodium contents of $1.0 \mathrm{M}$ became typical. For SB3, Tank 51 was washed to $1.8 \mathrm{M}$ sodium and had a nitrite concentration of $0.72 \mathrm{M}$ resulting in the blended material in Tank 40 having a sodium concentration of $1.00 \mathrm{M}$ and nitrite concentration of $0.43 \mathrm{M}$. The current DWPF feed batch, SB7b, was washed to a sodium content of $1.4 \mathrm{M}$ in Tank 51, while future batches could be washed to as high as $2.5 \mathrm{M}$ sodium to ensure an acceptable glass composition processing window. SB8 operating windows in glass compositional space indicate that a washing target of $2.0 \mathrm{M}$ is necessary to achieve operating windows with and without ARP addition using one frit assuming a nominal targeted waste loading of at least $36 \% .{ }^{2}$ Minimal washing is also desired to prevent removal of oxalate from oxalic acid cleaning of Tank 12 during washing; therefore SB8 could be washed to the higher end of the sodium target. A preliminary review of the System Plan Rev. $17^{3}$ indicates that out-year batches may need to be less washed to meet DWPF processing goals. In addition, less washing generates less volume of supernate, allowing tank space to be devoted to handling the current inventory and generated waste from operating facilities such as the DWPF.

Based on past batches, less washed sludges are expected to have smaller acid windows (as determined by the range of allowable stoichiometric factors) than more washed sludges. Hydrogen generation rate is driven by the amount of excess formic acid coupled with the mercury and noble metal concentrations. The acid demand for less washed sludge is higher, therefore percentage changes equate to larger changes in the total acid and excess acid amounts and the uncertainties in the inputs to the DWPF stoichiometric acid equation becomes more important. An acid window of at least $30 \%$ per the Koopman and Hsu equation ${ }^{4,5,6}$ is the most desirable outcome, although DWPF processing could be performed with a slightly smaller window by targeting a stoichiometric factor below the midpoint of the window and adding additional acid to any SRAT batches that failed to destroy nitrite. This second option, however, could impact DWPF cycle times and could potentially lead to reduced canister production.

The goal of the experiments detailed in this report was to determine the impact to CPC processing of less washed sludges. ${ }^{7,8}$ It was expected that Tank 51 SB8 sludge would be washed to a sodium end point between $2 \mathrm{M}$ and $2.5 \mathrm{M}$ sodium. When blended with Tank 40 , it was projected that the SB8 sodium concentration would be $1.6 \mathrm{M}$ to $1.9 \mathrm{M}$ in the DWPF feed and nitrite concentrations of $0.387 \mathrm{M}$ to $0.459 \mathrm{M}$. Throughout this report, the identifications of $2 \mathrm{M}$ and $2.5 \mathrm{M}$ are used to indicate the targeted wash endpoints in Tank 51 rather than the molarities in Tank 40, even though testing was performed with Tank 40 compositions.

\subsection{Experimental Procedure}

\subsection{Process and Sample Analytical Methods}

The automated data acquisition system developed for the 4-L SRAT rigs was used to collect electronic data on a computer. Collected data included Sludge Receipt and Adjustment Tank (SRAT) slurry temperature, bath temperatures for the cooling water to the SRAT condenser and Formic Acid Vent Condenser (FAVC), slurry pH, SRAT mixer speed and torque, air and helium purge flows; helium is used as an internal standard and is set to $0.5 \%$ of the nominal SRAT air purge flow. Cumulative acid addition volume data were collected using an algorithm for pump 
speed and time versus volume delivered. Raw Gas Chromatograph (GC) data were acquired on a separate computer interfaced to the data acquisition computer.

Agilent 3000A micro GC's were used for all runs. The GC's were baked out prior to the runs each week. Column-A can collect data related to $\mathrm{He}, \mathrm{H}_{2}, \mathrm{O}_{2}, \mathrm{~N}_{2}$, NO, and CO, while column-B can collect data related to $\mathrm{CO}_{2}, \mathrm{~N}_{2} \mathrm{O}$, and water. GC's were calibrated with a standard calibration gas containing 0.510 vol\% $\mathrm{He}, 1.000$ vol\% $\mathrm{H}_{2}, 20.10$ vol\% $\mathrm{O}_{2}, 50.77$ vol\% $\mathrm{N}_{2}, 25.1 \mathrm{vol} \% \mathrm{CO}_{2}$ and $2.52 \mathrm{vol} \% \mathrm{~N}_{2} \mathrm{O}$. The calibration was verified prior to starting the SRAT cycle and after completing the Slurry Mix Evaporator (SME) cycle. Room air was used to give a two point calibration for $\mathrm{N}_{2}$ and to check the calibration. The chilled off-gas leaving the FAVC was passed through a Nafion dryer in counter-current flow with a dried air stream to reduce the moisture content at the GC inlet. The dried, chilled off-gas stream was sampled by a GC from the beginning of heat-up to temperature to start the SRAT cycle through most of the cool down following the SME cycle.

Process samples were analyzed by various methods. Slurry and supernate elemental compositions were determined by inductively coupled plasma-atomic emission spectroscopy (ICP-AES) after lithium metaborate and sodium peroxide fusions at the Process Science Analytical Laboratory (PSAL). Slurry samples were calcined at $1100^{\circ} \mathrm{C}$. The main advantage of this approach was to permit easier comparisons between SRAT product elements and sludge elements. Noble metals and mercury were trimmed uniquely to each SRAT, and their concentrations are known more accurately from material balance considerations than they could be from ICP-AES analyses.

Water soluble slurry anions were determined by ion chromatography (IC) on 100-fold weighted dilutions of slurry with water followed by filtration to remove the remaining insoluble solids. SRAT cycle, SRAT product, and SME product slurry samples were submitted to PSAL for mercury analysis by ICP-AES. Samples were submitted to Analytical Development (AD) for total inorganic carbon analysis of both the starting slurry and the supernate. Samples were analyzed by PSAL for slurry and supernate density using the Anton-Parr DM-4500 instrument. Starting sludges were titrated to $\mathrm{pH} 7$ using an auto-titrator to determine the base equivalents for input into the stoichiometric acid equation. Samples from the ammonia scrubber reservoir vessel were analyzed by $\mathrm{AD}$ using cation chromatography for ammonium ion.

Gas chromatograph off-gas data were scaled to DWPF flow rates. The calculation methodology has been previously documented. ${ }^{9}$ An internal standard flow was established with helium. Other gas flow rates were determined relative to helium by taking the ratio of the two gas volume percentages times the helium standard flow. The results were scaled by the ratio of 6,000 gallons of fresh sludge divided by the volume of fresh sludge in the simulant SRAT charge.

An Extrel ${ }^{\circledR}$ MAX300LG mass spectrometer (MS) was used to measure the gas composition exiting the processes. Both concurrent SRAT runs were analyzed. The MS uses a multiport switching valve to select the sample stream. The samples were pulled through the MS using a single diaphragm sample pump on the outlet of the MS sampling port. When not being sampled by the MS, the other sample stream still flowed continuously through a bypass port so the sample would always be fresh. The two sample streams were alternately analyzed for approximately 2.87 minutes with a 30 second delay during switching to purge out the previous sample stream. The MS was calibrated with a series of calibration gases. The MS measured the composition of the sample approximately every 7 seconds. 
Process mass spectrometry measures the intensity of ion signals and converts these signals to concentrations using the calibration data. Because some gases have interfering ions (e.g., $\mathrm{N}_{2}$ is measured at mass/charge $(\mathrm{m} / \mathrm{z})$ of $28\left(\mathrm{~N}_{2}^{+}\right) ; \mathrm{CO}_{2}$ is measured at $\mathrm{m} / \mathrm{z} 44$, and has an interfering ion fragment at $\mathrm{m} / \mathrm{z}$ of 28 from $\mathrm{CO}^{+}$that must be subtracted from the total signal at $\mathrm{m} / \mathrm{z} 28$ to give the correct signal for $\mathrm{N}_{2}$. This 'fragment' calibration is done using a calibration gas, in this case $\mathrm{CO}_{2}$ in Ar. The gases $\mathrm{NO}_{2}, \mathrm{NO}, \mathrm{N}_{2} \mathrm{O}$, and $\mathrm{CO}_{2}$ all have fragments that interfere at other $\mathrm{m} / \mathrm{z}$ values. The signals are calibrated with calibration gases; the calibration factors determined are termed "sensitivity". Background signals at each measurement $\mathrm{m} / \mathrm{z}$ were measured in pure $\mathrm{N}_{2}$ and Ar. The calibration gases used are summarized in Table 1.

Table 1. Mass Spectrometer Calibration Gases

\begin{tabular}{|rl|}
\hline \multicolumn{1}{|c|}{ Gas } & \multicolumn{1}{c|}{ Purpose } \\
\hline $\mathrm{Ar}$ & background signals at m/z 28 \& 30 \\
\hline $\mathrm{N}_{2}$ & background signals at m/z 2, 4, 32, 40, 44, 46 \\
\hline $20 \% \mathrm{CO}_{2}$ in $\mathrm{Ar}$ & $\mathrm{CO}_{2}$ fragment at m/z 28 \\
\hline $5 \% \mathrm{NO}_{2}$ in $\mathrm{N}_{2}+\mathrm{O}_{2}$ & $\mathrm{NO}_{2}$ fragment at m/z 30, calibration for $\mathrm{NO}_{2} \mathrm{~m} / \mathrm{z} 46$ \\
\hline $2 \% \mathrm{H}_{2}, 1 \% \mathrm{He}, 20 \% \mathrm{O}_{2}, 10 \%$ & calibration of each gas (m/z 2, 4, 32, 44, 40, \\
$\mathrm{CO}_{2}, 1 \% \mathrm{Ar}, 66 \% \mathrm{~N}_{2}$ & respectively); $\mathrm{N}_{2}$ sensitivity = 1.000 by definition) \\
\hline $2 \% \mathrm{NO}$ in $\mathrm{Ar}$ & calibration for NO at m/z 30 \\
\hline
\end{tabular}

The presence of $\mathrm{N}_{2} \mathrm{O}$ in the process gas introduces error in the measurements of $\mathrm{CO}_{2}, \mathrm{NO}$, and $\mathrm{N}_{2}$ because it has fragments with $\mathrm{m} / \mathrm{z}$ at the measurement masses of each of these gases. The MS cannot be calibrated for $\mathrm{N}_{2} \mathrm{O}$ because the relative amount of $\mathrm{N}_{2} \mathrm{O}$ to the other gases is too small to give a reliable calibration. The presence of $1.2 \% \mathrm{~N}_{2} \mathrm{O}$ (the highest measured by GC) would result in the measurement of $\mathrm{N}_{2}$ being high by about $0.12 \%$, $\mathrm{NO}$ being high by about $0.24 \%$, and $\mathrm{CO}_{2}$ being high by about $0.86 \%$.

An MKS ${ }^{\circledR}$ MG2030 Fourier Transform Infrared Spectrometer (FTIR) was used to measure the gas composition of one of the SRAT rigs during each concurrent run. The sample location was the same as used for the GC and MS. The FTIR uses factory calibration data for the infrared spectra and does not need to be calibrated; it automatically adjusts for changes in signal strength. The gases measured by the FTIR were $\mathrm{CO}_{2}, \mathrm{~N}_{2} \mathrm{O}, \mathrm{NO}, \mathrm{NO}_{2}$, and HMDSO. It also had the ability to detect $\mathrm{CO}, \mathrm{NH}_{3}$, nitric acid, formic acid, and water, but no significant amounts were detected. Low ppm amounts of nitric and formic acids were detected during nitric and glycolic acid additions, but these values may have been due to interferences.

In general, the FTIR values matched the GC and MS values reasonably well. It must be noted that the concentrations in the process for $\mathrm{NO}, \mathrm{NO}_{2}$, and $\mathrm{CO}_{2}$ significantly exceeded the calibration data and so the FTIR values are extrapolations of the calibration curves. The raw spectral data will be analyzed for the presence of species not in the calibration library at a future date. Antifoam breakdown products such as trimethylsilanol and siloxanes larger than six carbons are possible species that could be found from the spectra by further analysis.

\subsection{Simulant Preparation and Characterization}

The test simulant was prepared from blends of Tank 4, Tank 7, and Tank 12 simulants originally prepared for SB7a and SB7b testing. The simulant was fabricated by the current continuous stirred tank reactor (CSTR) precipitation method. ${ }^{10}$ This method involved the following processing steps: 
- A slurry of precipitated $\mathrm{MnO}_{2}$ was prepared.

- An acidic metal nitrate solution was prepared.

- The two were combined and fed to the CSTR along with a $50 \mathrm{wt} \%$ sodium hydroxide solution to produce a slurry of hydrous metal oxide and hydroxide solids in a sodium nitrate solution at a $\mathrm{pH}$ of about 9.5.

- The slurry was contacted with sodium carbonate to permit conversion of some of the hydroxides to carbonates.

- The slurry was decanted and washed until the nitrate concentration was below the target supernate nitrate concentration.

- The slurry was concentrated to a point consistent with the targeted total solids value for the final slurry.

- Silica, $\mathrm{TiO}_{2}$, and sodium salts were added to complete the preparation.

This simulant was split into two batches that were adjusted to supernate compositions projected for SB8 in Tank 40 at sodium molarities. Table 2 presents the average elemental results of duplicate analyses of two slurry samples from the test simulant calcined at $1100^{\circ} \mathrm{C}$.

Table 2. Elemental composition of SRAT feeds calcined at $1100^{\circ} \mathrm{C}$, wt $\%$

\begin{tabular}{|c|c|c|c|}
\hline Element & $\begin{array}{c}\text { SB7b } \\
\text { WAPS }\end{array}$ & $\begin{array}{c}\text { 2M Na } \\
\text { Simulant }\end{array}$ & $\begin{array}{c}\text { 2.5M Na } \\
\text { Simulant }\end{array}$ \\
\hline $\mathrm{Al}$ & 7.34 & 16.0 & 16.4 \\
\hline $\mathrm{Ba}$ & 0.08 & 0.08 & 0.07 \\
\hline $\mathrm{Ca}$ & 0.56 & 0.58 & 0.51 \\
\hline $\mathrm{Cr}$ & 0.03 & 0.03 & 0.02 \\
\hline $\mathrm{Cu}$ & 0.03 & 0.04 & 0.04 \\
\hline $\mathrm{Fe}$ & 11.1 & 13.7 & 12.4 \\
\hline $\mathrm{K}$ & 0.04 & 0.34 & 0.41 \\
\hline $\mathrm{Mg}$ & 0.24 & 0.29 & 0.26 \\
\hline $\mathrm{Mn}$ & 2.47 & 4.63 & 4.23 \\
\hline $\mathrm{Na}$ & 11.5 & 23.3 & 24.0 \\
\hline $\mathrm{Ni}$ & 2.15 & 1.94 & 1.76 \\
\hline $\mathrm{P}$ & 0.09 & 0.03 & $<0.01$ \\
\hline $\mathrm{Pb}$ & 0.02 & 0.01 & 0.01 \\
\hline $\mathrm{S}$ & 0.39 & 0.24 & 0.30 \\
\hline $\mathrm{Si}$ & 0.89 & 1.55 & 1.30 \\
\hline $\mathrm{Ti}$ & 0.01 & 0.02 & 0.02 \\
\hline $\mathrm{Zn}$ & 0.03 & 0.05 & 0.04 \\
\hline $\mathrm{Zr}$ & 0.14 & 0.19 & 0.18 \\
\hline
\end{tabular}

Table 3 presents results for total, insoluble, soluble and calcined wt.\% solids, slurry and supernate density, slurry base equivalent molarity, slurry and supernate total inorganic carbon (TIC), and the slurry anion results from IC. The high sodium test simulant values are compared to the SB7b WAPS sample, which is currently being processed in the DWPF. 
Table 3. Simulant and Radioactive Feed Properties

\begin{tabular}{|l|c|c|c|}
\hline & $\begin{array}{c}\text { SB7b } \\
\text { WAPS }\end{array}$ & $\begin{array}{c}\text { 2M Na } \\
\text { Simulant }\end{array}$ & $\begin{array}{c}\text { 2.5M Na } \\
\text { Simulant }\end{array}$ \\
\hline Total solids, wt.\% & 15.6 & 24.1 & 25.4 \\
\hline Insoluble solids, wt.\% & 10.8 & 16.5 & 17.0 \\
\hline Soluble solids, wt.\% & 5.48 & 7.6 & 8.5 \\
\hline Calcined solids, wt.\% & 12.5 & 17.0 & 17.9 \\
\hline Slurry density, g/mL & 1.12 & 1.17 & 1.22 \\
\hline Supernate density, g/mL & 1.05 & 1.08 & 1.09 \\
\hline Slurry base equiv., mol/kg & 0.29 & 0.91 & 0.98 \\
\hline Nitrite, mg/kg slurry & 9,120 & 13,450 & 15,750 \\
\hline Nitrate, mg/kg slurry & 5,100 & 7,900 & 9,900 \\
\hline Sulfate, mg/kg slurry & 1,470 & 1,980 & 2,600 \\
\hline Oxalate, mg/kg slurry & 2,970 & 18,750 & 20,000 \\
\hline Chloride, mg/kg slurry & $<400$ & $<500$ & $<500$ \\
\hline Slurry TIC, mg/kg slurry & 1,610 & 1,840 & 1,732 \\
\hline Supernate TIC, mg/L supernate & 1,120 & 1,790 & 1,760 \\
\hline
\end{tabular}

The high sodium simulant SRAT simulations started with approximately 3,000 g of sodiumtrimmed starting sludge (before minor trim chemicals and rinse water). These were sludge-only tests and did not include coupled processing with streams from the Modular Caustic Side Solvent Extraction Unit (MCU/ARP) and the Actinide Removal Process (ARP).

Accurate projections for mercury and noble metals in SB8 sludge were not available prior to the acid window simulant testing. SB7b levels of mercury and noble metals were used, adjusted for dilution due to increased sodium. Rhodium was trimmed as a solution of $\mathrm{Rh}\left(\mathrm{NO}_{3}\right)_{3}$ containing 4.93 wt.\% Rh. Ruthenium was added as the dry trivalent chloride salt at a purity of 41.73 wt.\% $\mathrm{Ru}$. Palladium was trimmed as a solution of $\mathrm{Pd}\left(\mathrm{NO}_{3}\right)_{2}$ containing 15.27 wt.\% Pd. Silver was added as the dry nitrate salt $\mathrm{AgNO}_{3}$. Mercury was trimmed as dry $\mathrm{HgO}$ (yellow mercuric oxide, which is more finely ground than red mercuric oxide).

Targets for the two test simulants are given in Table 4 along with the reported values for the SB7b WAPS sample for comparison.

Table 4. Noble metal and mercury, wt \% in total solids

\begin{tabular}{|l|c|c|c|}
\hline & $\begin{array}{c}\text { SB7b } \\
\text { WAPS }\end{array}$ & $\begin{array}{c}\text { 2M Na } \\
\text { Simulant }\end{array}$ & $\begin{array}{c}\mathbf{2 . 5 M} \text { Na } \\
\text { Simulant }\end{array}$ \\
\hline Hg, wt\% & 1.710 & 1.500 & 1.410 \\
\hline Rh, wt\% & 0.0207 & 0.0192 & 0.0180 \\
\hline Ru, wt\% & 0.102 & 0.0877 & 0.0824 \\
\hline Pd, wt\% & 0.0025 & 0.0033 & 0.0031 \\
\hline Ag, wt\% & 0.0118 & 0.0144 & 0.0135 \\
\hline
\end{tabular}




\section{3 $\underline{\text { Chemical Process Cell Simulation Details }}$}

The trimmed SRAT receipt volume was about 3.0 L for the high sodium testing. The 4-L labscale SRAT equipment was used for these tests. A photo of the 4-L rig is shown in Figure 1. Details about the design are in the CPC equipment set-up reference. ${ }^{11}$

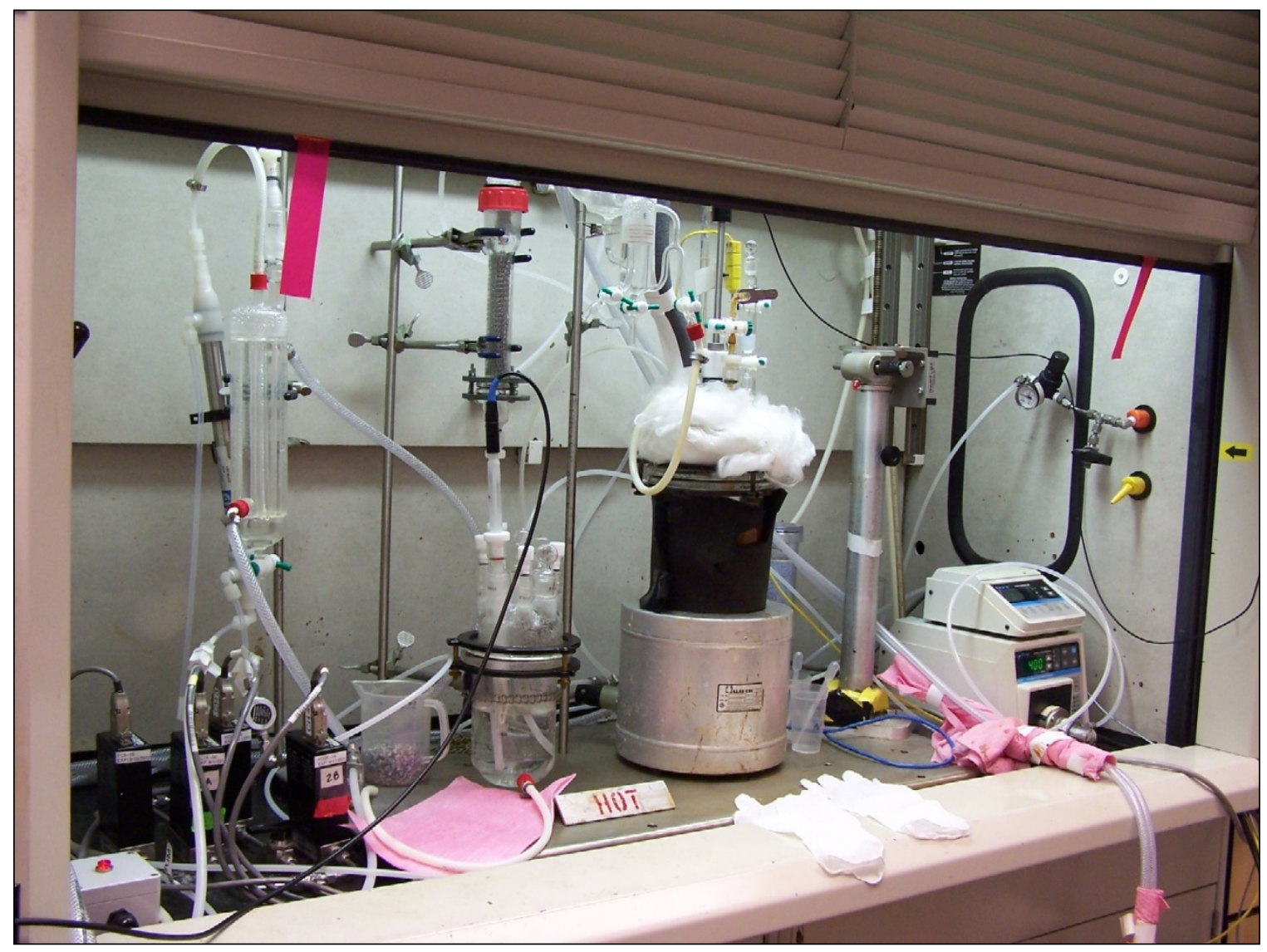

Figure 1. Lab-scale SRAT apparatus

The reservoir below the ammonia scrubber was charged with a solution of $749 \mathrm{~g}$ of de-ionized water and $1 \mathrm{~g}$ of $50 \mathrm{wt} . \%$ nitric acid. The dilute acid reservoir solution was recirculated by a MasterFlex driven Micropump gear pump at about $300 \mathrm{~mL}$ per minute to a spray nozzle at the top of the packed section.

Initial acid calculations were based on the Koopman minimum acid (KMA) requirement equation. $^{12}$

$$
\frac{\text { moles acid }}{L \text { slurry }}=\text { base equivalents }+\mathrm{Hg}+\text { soluble } \mathrm{TIC}+1.5 *(\mathrm{Ca}+\mathrm{Mg})+1.0 * \text { nitrite }+1.5 * \mathrm{Mn}
$$

Four different stoichiometric factors were used in the acid calculations, $100 \%, 110 \%, 125 \%$, and $130 \%$. Run identification for these experiments used the nominal Tank 51 sodium concentration followed by the percent acid stoichiometry, e.g. $2 \mathrm{M}-100$ for the $1.6 \mathrm{M}$ simulant at $100 \% \mathrm{KMA}$. Acid calculations were also performed using the current DWPF algorithm for comparison: ${ }^{13}$ 


$$
\frac{\text { moles acid }}{L \text { slurry }}=\text { base equivalents }+2 * \text { total TIC }+0.75 * \text { nitrite }+1.2 * \mathrm{Mn}+\mathrm{Hg}
$$

The results of these two calculations for the $2 \mathrm{M}$ and $2.5 \mathrm{M}$ simulants are summarized in Table 5 . The table also includes the actual acid additions made based on the Koopman minimum acid equation (maximum acid) and the equivalent DWPF stoichiometric factors (percent) to go from the DWPF acid equation values to the actual acid additions. The total acid was partitioned between formic and nitric acids using the current RedOx equation. ${ }^{14}$

Table 5. Stoichiometric acid calculation results, moles acid/L trimmed slurry

\begin{tabular}{|l|c|c|c|c|}
\hline & $\begin{array}{c}\text { DWPF Eqn. } \\
\text { moles/L }\end{array}$ & $\begin{array}{c}\text { Koopman Min. } \\
\text { moles/L }\end{array}$ & KMA Factor & $\begin{array}{c}\text { Equivalent } \\
\text { DWPF factor }\end{array}$ \\
\hline $2 \mathrm{M}-100$ & 1.679 & 1.669 & $100 \%$ & $99.4 \%$ \\
\hline $2 \mathrm{M}-110$ & 1.679 & 1.669 & $110 \%$ & $109 \%$ \\
\hline $2 \mathrm{M}-125$ & 1.679 & 1.669 & $125 \%$ & $124 \%$ \\
\hline $2 \mathrm{M}-130$ & 1.679 & 1.669 & $130 \%$ & $129 \%$ \\
\hline $2.5 \mathrm{M}-100$ & 1.764 & 1.780 & $100 \%$ & $101 \%$ \\
\hline $2.5 \mathrm{M}-130$ & 1.764 & 1.780 & $130 \%$ & $131 \%$ \\
\hline
\end{tabular}

Scaled design basis DWPF SRAT/SME processing conditions were generally used. The SRAT and SME cycles, however, did not have a heel from a prior batch. R\&D directions were prepared for each run and used to supplement the standard SRNL procedure for non-radioactive CPC simulations. ${ }^{15}$ The following parameters were used:

- The SRAT air purge scaled to $230 \mathrm{scfm}$ in DWPF.

- A 100 ppm antifoam addition was made prior to nitric acid addition.

- A 100 ppm antifoam addition was made prior to formic acid addition.

- Nitric and formic acid addition were made at $93{ }^{\circ} \mathrm{C}$.

- Acids were added at two gallons per minute scaled per the discussion below.

- A 500 ppm antifoam addition was made prior to going to boiling following acid addition.

- Boiling assumed a condensate production rate of 5,000 lb/hr at DWPF scale.

- SRAT dewatering took about 3.6-4.0 hours to produce a $25 \mathrm{wt} \%$ total solids slurry.

- Reflux followed dewatering. The end of the 12-hour reflux period defined the end of the SRAT cycle (theoretically this was sufficient to strip mercury to specifications).

- The SME air purge scaled to 74 scfm in DWPF.

- A 100 ppm antifoam addition was made at the start of the SME cycle.

- Canister decontamination water additions and dewaterings were not simulated.

- Two frit 418-water-formic acid additions were made targeting 36\% waste loading.

- The SME was dewatered following each frit slurry addition.

- The final SME solids target was $48 \mathrm{wt} \%$.

Samples were taken during each SRAT cycle to monitor the progress of the main reactions. Major cations and anions were checked immediately after acid addition. Samples were pulled during boiling to monitor suspended and dissolved mercury in the SRAT slurry. These samples were pulled directly into digestion vials to eliminate potential segregation of mercury during subsampling/aliquoting steps. The SRAT and SME product slurries were sampled similarly once they had cooled to $90{ }^{\circ} \mathrm{C}$ while the vessel contents were still mixing. 
Additional SRAT product samples were taken for compositional and solids analyses after the product had cooled further. The Mercury Water Wash Tank (MWWT) and FAVC were drained and the condensates weighed after both the SRAT and SME cycles.

\subsection{Results and Discussion}

\section{1 $\underline{\text { SRAT Cycle }}$}

The six simulant SRAT cycles are discussed below. Chemical and physical data from process samples will be presented first followed by off-gas data.

\subsubsection{SRAT Cycle Slurry Samples}

Formate loss and nitrite/nitrate results are presented in Table 6 for the SRAT product.

Table 6. SRAT Anion Reactions

\begin{tabular}{|l|c|c|c|c|c|c|}
\hline & 2M & 2M & 2M & 2M & 2.5M & 2.5M \\
\hline KMA stoichiometry, \% & 100 & 110 & 125 & 130 & 100 & 130 \\
\hline Formate loss, \% & 18 & 24 & 42 & 39 & 20 & 39 \\
\hline Nitrite-to-nitrate, \% & 5.6 & 6.9 & 2.1 & 1.9 & 6.7 & 1.9 \\
\hline Nitrite loss, \% & 69 & 90 & 100 & 100 & 66 & 100 \\
\hline
\end{tabular}

The low nitrite-to-nitrate conversion numbers suggest ammonium ion formation was occurring during boiling. Table 7 reports the anion analytical data for the SRAT products. Acid stoichiometry runs from $110 \%$ to $130 \%$ met the nitrite constraint of $<1000 \mathrm{mg} / \mathrm{kg}$ slurry by destroying all nitrite. However, the lower acid stoichiometry runs (100\%) failed the nitrite constraint. From this data, it appears that $110 \%$ stoichiometry was essentially the minimum acid that would achieve adequate nitrite destruction for these levels of noble metals. The reason for the additional acid needed above the KMA requirement to destroy nitrite was likely due to the high oxalate concentrations of these simulants. Formate loss generally increased with increasing acid stoichiometry. Slurry oxalate is not reported due to issues with the analytical method.

Table 7. SRAT Product Anions, mg/kg slurry

\begin{tabular}{|c|c|c|c|c|c|c|}
\hline Anions & $\mathbf{2 M}$ & $\mathbf{2 M}$ & $\mathbf{2 M}$ & $\mathbf{2 M}$ & $\mathbf{2 . 5 M}$ & $\mathbf{2 . 5 M}$ \\
\hline KMA stoichiometry, \% & 100 & 110 & 125 & 130 & 100 & 130 \\
\hline $\mathrm{NO}_{2}{ }^{-}$ & 4,140 & 620 & $<500$ & $<500$ & 5,285 & $<500$ \\
\hline $\mathrm{NO}_{3}{ }^{-}$ & 25,550 & 27,950 & 23,000 & 30,250 & 27,500 & 28,250 \\
\hline $\mathrm{SO}_{4}{ }^{-}$ & 1,510 & 1,460 & 1,380 & 1,780 & 1,900 & 1,400 \\
\hline $\mathrm{HCO}_{2}^{-}$ & 46,550 & 47,150 & 40,800 & 44,700 & 47,650 & 43,600 \\
\hline
\end{tabular}

Elemental wt.\% data for the six SRAT products calcined at $1100{ }^{\circ} \mathrm{C}$ are given in Table 8. Lead, chromium, and the noble metals (not listed) tend to be underreported in SRAT product calcined solids. Normal variations are seen in the results for each sodium molarity associated with the analytical uncertainty of the ICP-AES measurement method. 
Table 8. SRAT Calcined Elements at $1100{ }^{\circ} \mathrm{C}-w t . \%$

\begin{tabular}{|c|c|c|c|c|c|c|}
\hline Run ID & 2M-100 & 2M-110 & 2M-125 & 2M-130 & 2.5M-100 & 2.5M130 \\
\hline $\mathrm{Al}$ & 15.5 & 15.8 & 15.9 & 16.9 & 16.3 & 16.2 \\
\hline $\mathrm{Ba}$ & 0.08 & 0.08 & 0.08 & 0.08 & 0.07 & 0.10 \\
\hline $\mathrm{Ca}$ & 0.54 & 0.55 & 0.54 & 0.57 & 0.49 & 0.63 \\
\hline $\mathrm{Cr}$ & 0.03 & 0.03 & 0.04 & 0.02 & 0.02 & 0.02 \\
\hline $\mathrm{Cu}$ & 0.03 & 0.04 & 0.03 & 0.02 & 0.03 & 0.02 \\
\hline $\mathrm{Fe}$ & 14.4 & 14.4 & 13.0 & 13.6 & 13.2 & 15.1 \\
\hline $\mathrm{K}$ & 0.33 & 0.33 & 0.32 & 0.38 & 0.37 & 0.36 \\
\hline $\mathrm{Mg}$ & 0.30 & 0.31 & 0.30 & 0.30 & 0.27 & 0.32 \\
\hline $\mathrm{Mn}$ & 4.64 & 4.76 & 4.74 & 4.24 & 4.22 & 4.65 \\
\hline $\mathrm{Na}$ & 22.8 & 23.4 & 23.6 & 24.7 & 24.4 & 23.4 \\
\hline $\mathrm{Ni}$ & 2.09 & 1.73 & 1.73 & 1.85 & 1.90 & 2.09 \\
\hline $\mathrm{S}$ & 0.28 & 0.30 & 0.30 & 0.34 & 0.35 & 0.29 \\
\hline $\mathrm{Si}$ & 1.49 & 1.42 & 1.47 & 1.61 & 1.36 & 1.71 \\
\hline $\mathrm{Ti}$ & 0.03 & 0.03 & 0.03 & 0.02 & 0.02 & 0.02 \\
\hline $\mathrm{Zn}$ & 0.05 & 0.05 & 0.05 & 0.04 & 0.05 & 0.05 \\
\hline $\mathrm{Zr}$ & 0.19 & 0.20 & 0.20 & 0.18 & 0.18 & 0.20 \\
\hline
\end{tabular}

SRAT product solids data, densities, and $\mathrm{pH}$ are given in Table 9. The wt.\% insoluble and soluble solids were calculated from the measured total slurry and supernate (dissolved) solids. The density measurements were made at $25^{\circ} \mathrm{C}$.

Table 9. Additional SRAT Product Properties

\begin{tabular}{|l|c|c|c|c|c|c|}
\hline Run ID: & 2M-100 & 2M-110 & 2M-125 & 2M-130 & 2.5M-100 & 2.5M130 \\
\hline Wt. \% total solids & 25.3 & 24.7 & 24.5 & 27.2 & 27.1 & 25.2 \\
\hline Wt. \% insoluble solids & 13.3 & 12.4 & 13.5 & 15.4 & 14.3 & 13.0 \\
\hline Wt. \% soluble solids & 12.1 & 12.3 & 10.9 & 11.8 & 12.7 & 12.2 \\
\hline Wt. \% calcined solids & 16.9 & 16.4 & 16.0 & 16.7 & 17.8 & 15.6 \\
\hline Slurry density, g/mL & 1.198 & 1.195 & 1.193 & 1.192 & 1.215 & 1.178 \\
\hline Supernate density, g/mL & 1.092 & 1.093 & 1.086 & 1.089 & 1.103 & 1.089 \\
\hline Product pH at $25^{\circ} \mathrm{C}$ & 8.15 & 8.05 & 9.10 & 9.47 & 8.14 & 9.48 \\
\hline
\end{tabular}

The evolution of slurry pH during the SRAT cycle is shown in Figure 2. 


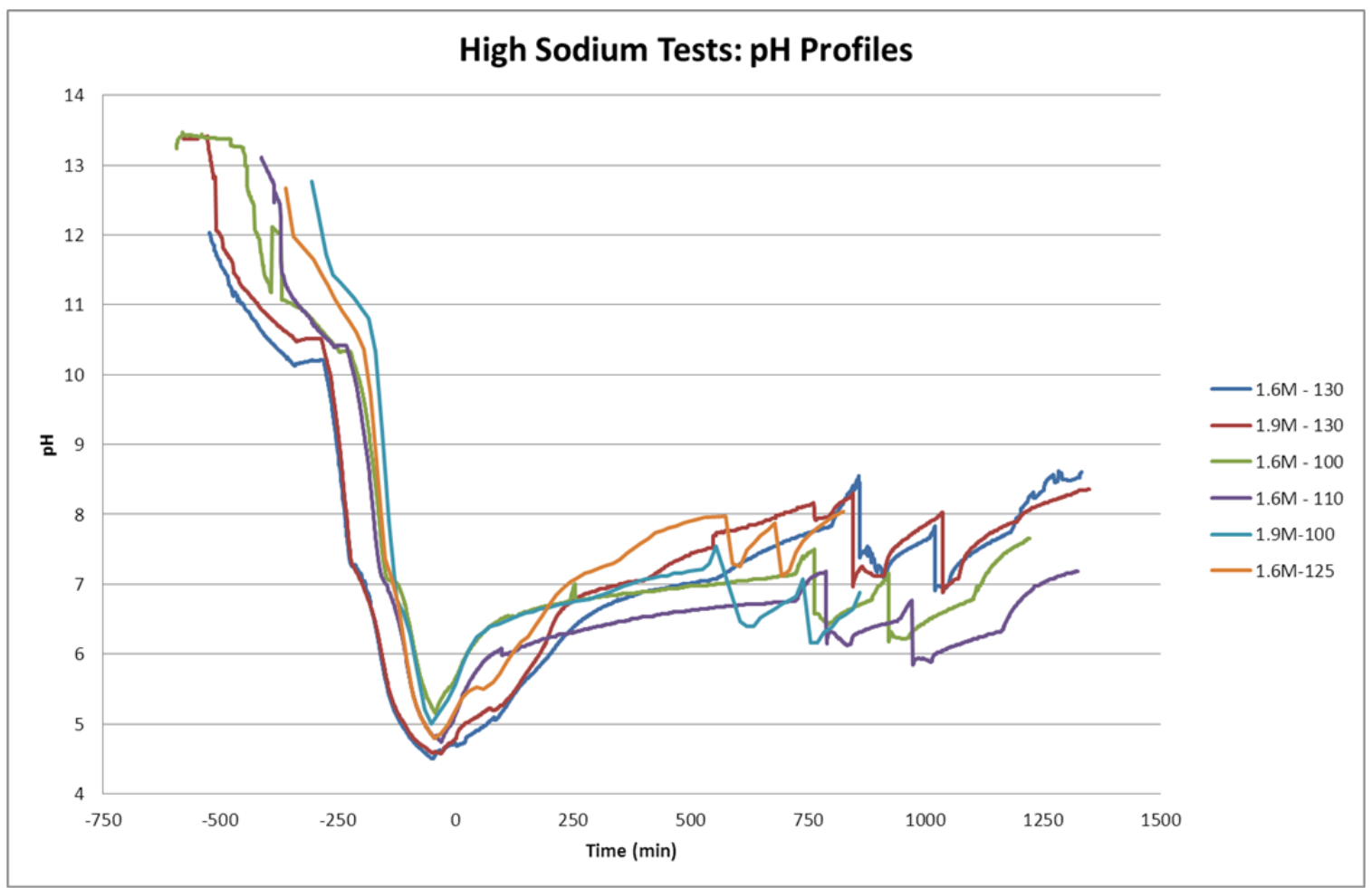

Figure 2. SRAT vessel $\mathrm{pH}$ readings versus time

The six pH curves ended between $\mathrm{pH} 7$ and 9 by the end of boiling. These results are consistent with historical pH results. SRAT and SME product samples had $\mathrm{pH}$ from 8-9.5 measured at room temperature.

\subsubsection{SRAT Element Solubility}

Supernate samples were taken between acid addition and the end of the SRAT cycle to determine the soluble cations. The percentages of selected total elements found in the supernate phase following formic acid addition are given in Table 10. The low solubilities of Ca and $\mathrm{Mg}$ are typical of SRAT products in the presence of excess oxalate ion. Values in excess of $100 \%$ are possible if there are volatile losses of the slurry elements during calcination. 
Table 10. Dissolution percent of elements following formic acid

\begin{tabular}{|c|c|c|c|c|}
\hline Run ID: & $\mathbf{2 M - 1 0 0}$ & $\mathbf{2 M - 1 3 0}$ & $\mathbf{2 . 5 M - 1 0 0}$ & $\mathbf{2 . 5 M - 1 3 0}$ \\
\hline $\mathrm{Al}$ & 1.48 & 1.87 & 1.58 & 1.21 \\
\hline $\mathrm{Ba}$ & 0.76 & 1.65 & 1.12 & 0.76 \\
\hline $\mathrm{Ca}$ & 3.81 & 11.8 & 5.44 & 0.45 \\
\hline $\mathrm{Cr}$ & 27.0 & 44.5 & 47.0 & 29.9 \\
\hline $\mathrm{Cu}$ & 15.4 & 36.1 & 26.4 & 35.6 \\
\hline $\mathrm{Fe}$ & 0.17 & 0.90 & 0.54 & 0.18 \\
\hline $\mathrm{K}$ & 123 & 83.1 & 124 & 113 \\
\hline $\mathrm{Mg}$ & 8.94 & 19.7 & 13.3 & 11.5 \\
\hline $\mathrm{Mn}$ & 23.2 & 38.9 & 22.2 & 17.5 \\
\hline $\mathrm{Na}$ & 75.9 & 64.3 & 72.2 & 84.9 \\
\hline $\mathrm{Ni}$ & 0.25 & 3.37 & 0.49 & 8.76 \\
\hline $\mathrm{S}$ & 74.8 & 64.3 & 74.2 & 120 \\
\hline $\mathrm{Si}$ & 1.21 & 0.83 & 1.30 & 0.43 \\
\hline $\mathrm{Zn}$ & $\mathrm{BDL}$ & $\mathrm{BDL}$ & $\mathrm{BDL}$ & 2.50 \\
\hline $\mathrm{Zr}$ & 2.11 & $\mathrm{BDL}$ & 7.28 & 6.92 \\
\hline
\end{tabular}

BDL $=$ Below Detection Limit

Supernate samples were taken four hours into reflux and are presented in Table 11.

Table 11. Dissolution percent of elements after four hours reflux

\begin{tabular}{|c|c|c|c|c|}
\hline Run ID: & 2M-100 & 2M-130 & 2.5M-100 & 2.5M-130 \\
\hline $\mathrm{Al}$ & 0.03 & 5.82 & 0.03 & 2.22 \\
\hline $\mathrm{Ba}$ & 1.04 & 3.82 & 1.08 & 1.95 \\
\hline $\mathrm{Ca}$ & 0.46 & 3.17 & 0.59 & 11.3 \\
\hline $\mathrm{Cr}$ & 1.51 & 1.90 & 2.35 & 80.9 \\
\hline $\mathrm{Cu}$ & 12.8 & 1.35 & 16.3 & 63.7 \\
\hline $\mathrm{Fe}$ & $\mathrm{BDL}$ & 0.09 & $\mathrm{BDL}$ & 1.06 \\
\hline $\mathrm{K}$ & 184 & 107 & 181 & 142 \\
\hline $\mathrm{Mg}$ & 7.29 & 18.7 & 10.1 & 28.9 \\
\hline $\mathrm{Mn}$ & 13.2 & 25.6 & 12.1 & 37.3 \\
\hline $\mathrm{Na}$ & 106 & 81.4 & 95.5 & 105 \\
\hline $\mathrm{Ni}$ & 1.74 & 1.65 & 4.37 & 0.64 \\
\hline $\mathrm{S}$ & 108 & 80.5 & 105 & 191 \\
\hline $\mathrm{Si}$ & 6.96 & 1.10 & 3.15 & 13.7 \\
\hline $\mathrm{Zn}$ & $\mathrm{BDL}$ & $\mathrm{BDL}$ & $\mathrm{BDL}$ & $\mathrm{BDL}$ \\
\hline $\mathrm{Zr}$ & $\mathrm{BDL}$ & $\mathrm{BDL}$ & $\mathrm{BDL}$ & 6.95 \\
\hline
\end{tabular}

BDL = Below Detection Limit 
Table 12. Dissolution percent of elements after eight hours reflux

\begin{tabular}{|c|c|c|c|c|}
\hline Run ID: & $\mathbf{2 M - 1 0 0}$ & $\mathbf{2 M - 1 3 0}$ & $\mathbf{2 . 5 M - 1 0 0}$ & $\mathbf{2 . 5 M - 1 3 0}$ \\
\hline $\mathrm{Al}$ & 0.01 & BDL & 0.01 & BDL \\
\hline $\mathrm{Ba}$ & 1.13 & 0.99 & 1.01 & BDL \\
\hline $\mathrm{Ca}$ & 0.41 & 0.58 & 0.40 & 0.43 \\
\hline $\mathrm{Cr}$ & 0.54 & 0.75 & 0.43 & 0.59 \\
\hline $\mathrm{Cu}$ & 10.0 & 1.37 & 9.91 & 2.08 \\
\hline $\mathrm{Fe}$ & $\mathrm{BDL}$ & 0.02 & $\mathrm{BDL}$ & BDL \\
\hline $\mathrm{K}$ & 182 & 116 & 175 & 156 \\
\hline $\mathrm{Mg}$ & 9.15 & 18.6 & 11.8 & 14.7 \\
\hline $\mathrm{Mn}$ & 12.2 & 21.2 & 7.45 & 10.1 \\
\hline $\mathrm{Na}$ & 99.7 & 88.1 & 98.0 & 104 \\
\hline $\mathrm{Ni}$ & 2.87 & 2.72 & 4.53 & 1.72 \\
\hline $\mathrm{S}$ & 108 & 82.4 & 100 & 171 \\
\hline $\mathrm{Si}$ & 8.65 & 1.34 & 33.9 & 2.41 \\
\hline $\mathrm{Zn}$ & BDL & BDL & BDL & BDL \\
\hline $\mathrm{Zr}$ & BDL & BDL & BDL & BDL \\
\hline
\end{tabular}

BDL = Below Detection Limit

The SRAT cycle ended after twelve hours of reflux. By the end of reflux, mostly only $\mathrm{K}$ and $\mathrm{Na}$ remained soluble ( $\mathrm{S}$ is probably sulfate, an anion), as seen in Table 13.

Table 13. Dissolution percent of elements after twelve hours reflux

\begin{tabular}{|c|c|c|c|c|}
\hline Run ID: & $\mathbf{2 M - 1 0 0}$ & $\mathbf{2 M - 1 3 0}$ & $\mathbf{2 . 5 M - 1 0 0}$ & $\mathbf{2 . 5 M - 1 3 0}$ \\
\hline $\mathrm{Al}$ & BDL & BDL & BDL & BDL \\
\hline $\mathrm{Ba}$ & 0.16 & 0.60 & 0.29 & 0.60 \\
\hline $\mathrm{Ca}$ & 0.30 & 0.18 & 0.25 & 0.16 \\
\hline $\mathrm{Cr}$ & $\mathrm{BDL}$ & 0.52 & BDL & 0.47 \\
\hline $\mathrm{Cu}$ & 8.40 & 2.47 & 6.33 & 1.64 \\
\hline $\mathrm{Fe}$ & BDL & BDL & BDL & BDL \\
\hline $\mathrm{K}$ & 147 & 122 & 178 & 124 \\
\hline $\mathrm{Mg}$ & 9.66 & 11.4 & 7.51 & 4.95 \\
\hline $\mathrm{Mn}$ & 7.86 & 6.17 & 7.81 & 0.61 \\
\hline $\mathrm{Na}$ & $\mathrm{N} / \mathrm{A}$ & 81.13 & $\mathrm{~N} / \mathrm{A}$ & 91.3 \\
\hline $\mathrm{Ni}$ & 1.91 & 1.37 & 1.71 & 0.33 \\
\hline $\mathrm{S}$ & 109 & 100 & 157 & 109 \\
\hline $\mathrm{Si}$ & 1.40 & 1.78 & 1.28 & 1.09 \\
\hline $\mathrm{Zn}$ & BDL & BDL & BDL & BDL \\
\hline $\mathrm{Zr}$ & BDL & BDL & BDL & BDL \\
\hline
\end{tabular}

BDL = Below Detection Limit

\subsubsection{SRAT Off-gas Data}

The DWPF-scale hydrogen generation rates during the SRAT cycle are given in Figure 3. 


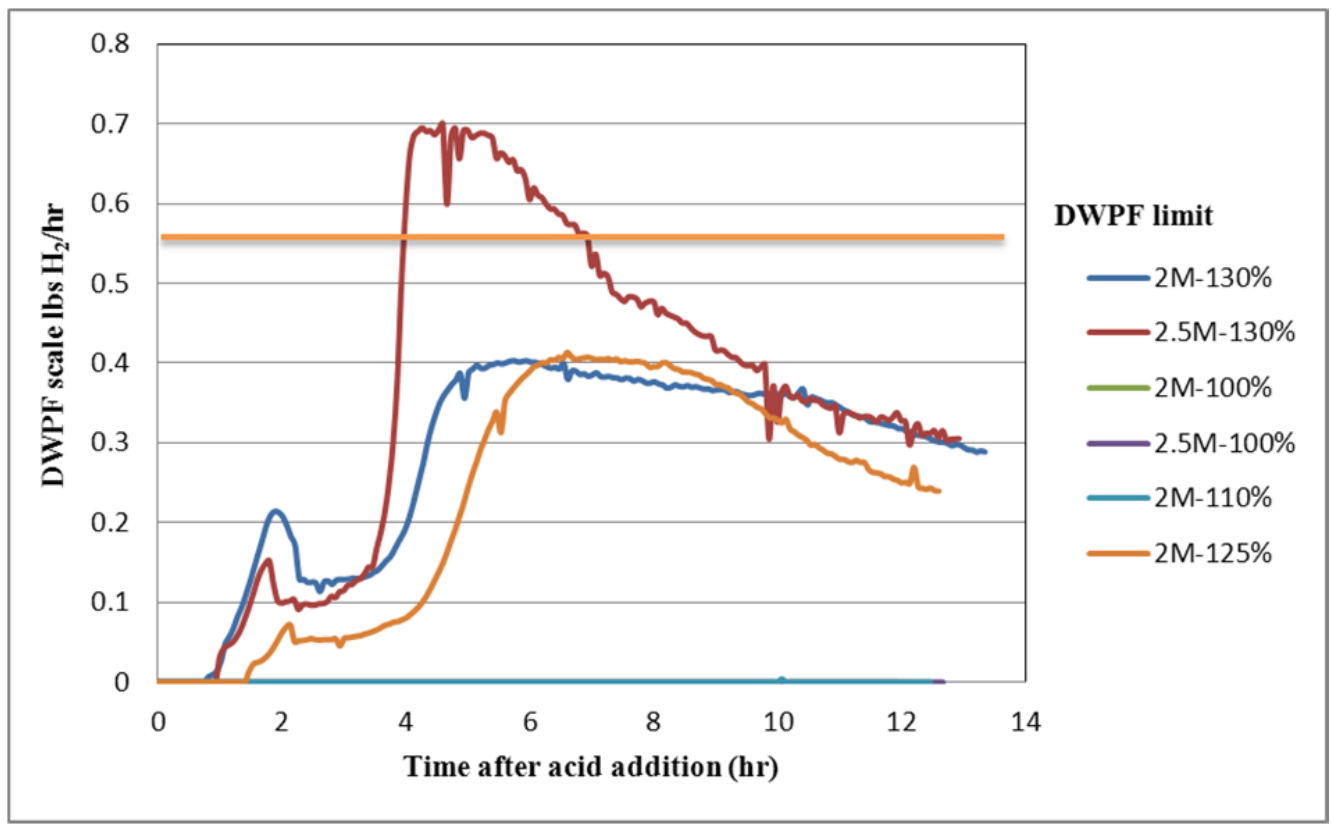

Figure 3. SRAT cycle hydrogen generation rates

The three lower acid runs had little to no hydrogen generation. As the acid stoichiometric factor increased, so did hydrogen generation. Of the six SRAT runs, only the 2.5M-130 run exceeded the DWPF SRAT hydrogen limit. The results at $2 \mathrm{M}$ for $125 \%$ and $130 \%$ acid, however, show how catalytically active the slurry was toward hydrogen generation. Table 14 presents numerical data for the amounts of hydrogen generated during the SRAT cycles.

Table 14. SRAT Cycle Hydrogen Generation

\begin{tabular}{|l|c|c|c|c|c|c|}
\hline Run ID: & 2M-100 & 2M-110 & 2M-125 & 2M-130 & 2.5M-100 & 2.5M130 \\
\hline Peak hydrogen, lb/h & 0 & 0 & 0.413 & 0.403 & 0 & 0.700 \\
\hline \% of SRAT limit & 0 & 0 & 64 & 62 & 0 & 108 \\
\hline
\end{tabular}

The carbon dioxide gas generation rate profiles are given in Figure 4. 


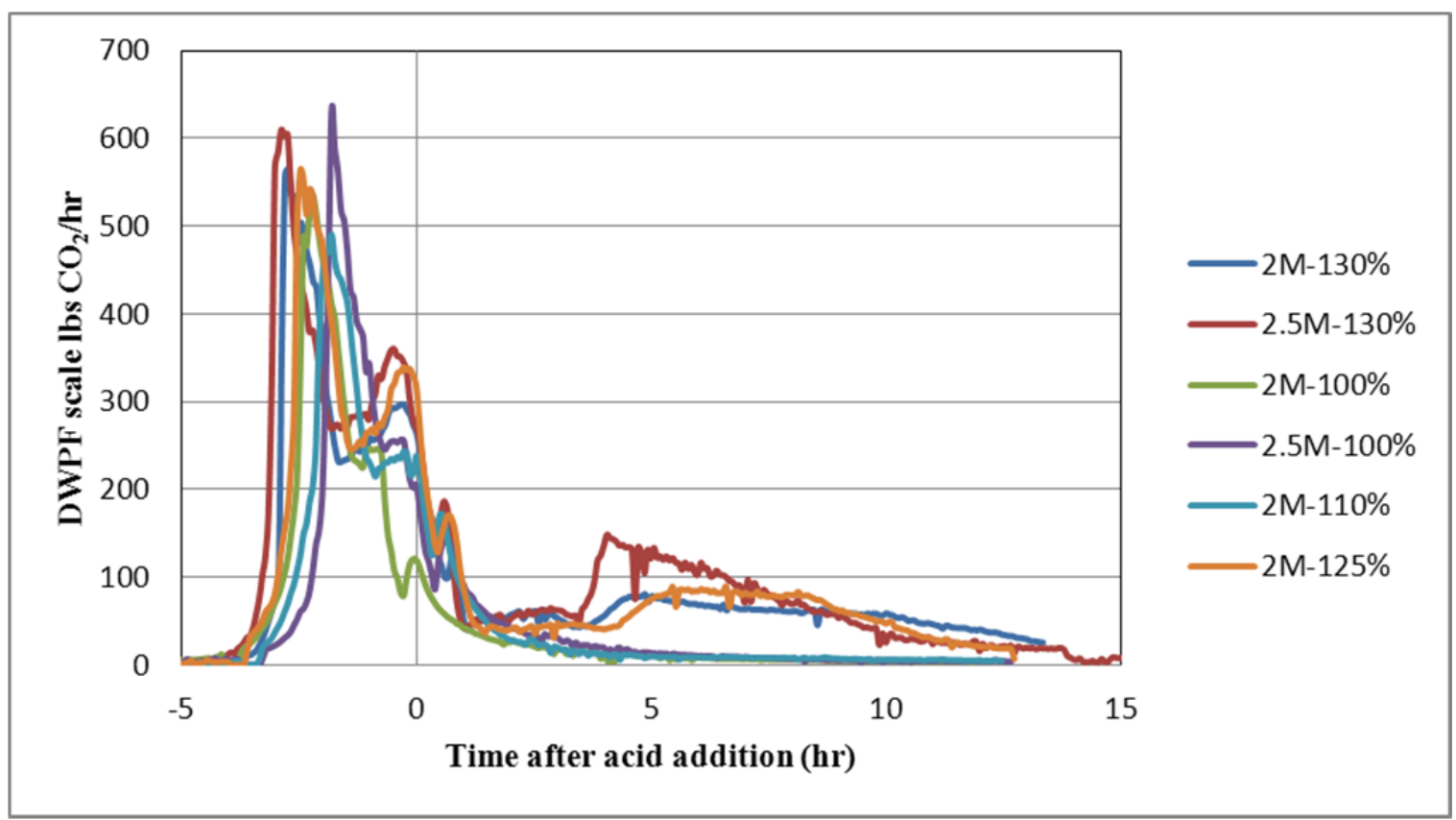

Figure 4. SRAT cycle $\mathrm{CO}_{2}$ during and after acid addition

Peaks in $\mathrm{CO}_{2}$ during boiling align with peaks in $\mathrm{H}_{2}$, as can be seen just prior to the 5 hour time. The $\mathrm{CO}_{2}$ traces are similar in peak height and shape during acid addition with exceptions made for the greater offgas occurring during formic acid decomposition for the higher acid runs and the somewhat longer acid addition time at higher stoichiometries. Numerical results for carbon dioxide generation are given in Table 15.

Table 15. SRAT Cycle Carbon Dioxide Generation

\begin{tabular}{|l|c|c|c|c|c|c|}
\hline Run ID: & 2M-100 & 2M-110 & 2M-125 & 2M-130 & 2.5M-100 & 2.5M130 \\
\hline Peak $\mathrm{CO}_{2}, \mathrm{lb} / \mathrm{h}$ & 535 & 490 & 564 & 566 & 632 & 610 \\
\hline Max vol\% & 23 & 22 & 25 & 25 & 28 & 27 \\
\hline Total $\mathrm{CO}_{2}, \mathrm{~g}$ & 51.2 & 55.2 & 94.1 & 94 & 56.1 & 115 \\
\hline
\end{tabular}

Off-gas data for $\mathrm{N}_{2} \mathrm{O}$ are presented in a similar manner to the data for $\mathrm{CO}_{2}$. A high range graph covering the period around acid addition is given in Figure 5. 


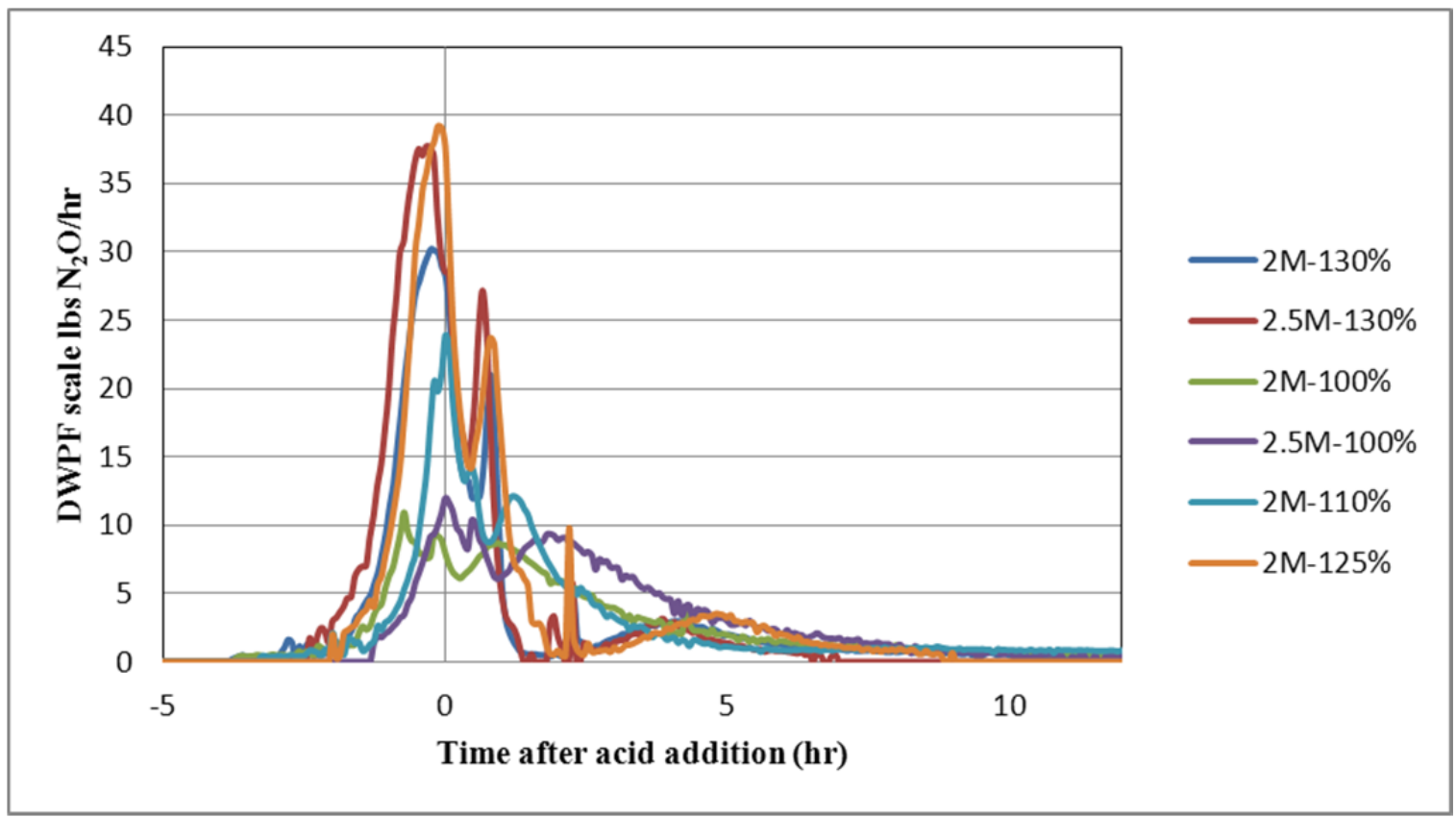

Figure 5. SRAT cycle $\mathrm{N}_{2} \mathrm{O}$ near the end of acid addition

The amount of $\mathrm{N}_{2} \mathrm{O}$ formed was a strong function of the acid stoichiometry. The total quantity of $\mathrm{N}_{2} \mathrm{O}$ produced nearly doubled with increased acid stoichiometry. The low acid runs clearly had significant undestroyed nitrite present when acid addition stopped based on these data. Some numerical $\mathrm{N}_{2} \mathrm{O}$ results are given in Table 16 .

Table 16. SRAT Cycle Nitrous Oxide Generation

\begin{tabular}{|l|c|c|c|c|c|c|}
\hline Run ID: & 2M-100 & 2M-110 & 2M-125 & 2M-130 & 2.5M-100 & 2.5M130 \\
\hline Peak $\mathrm{N}_{2} \mathrm{O}, \mathrm{lb} / \mathrm{h}$ & 11 & 24 & 39 & 30 & 12 & 38 \\
\hline Max vol\% & 0.58 & 1.4 & 2.2 & 1.6 & 0.70 & 2.1 \\
\hline Total $\mathrm{N}_{2} \mathrm{O}, \mathrm{g}$ & 2.3 & 2.6 & 3.5 & 3.0 & 2.5 & 3.5 \\
\hline
\end{tabular}

The three high acid runs appear to have destroyed nitrite around two hours after formic acid addition completed based on the $\mathrm{N}_{2} \mathrm{O}$ data. For the three lower acid runs, continued $\mathrm{N}_{2} \mathrm{O}$ generation was most likely due to the continuing destruction of the feed nitrite that continued into reflux. Nitrite destruction coincided with the onset of hydrogen generation, as expected. The reappearance of $\mathrm{N}_{2} \mathrm{O}$ in the high acid runs three hours past the end of acid addition was probably associated with the reaction sequence that can form ammonium ion.

\subsection{SME Cycle}

The six simulant SME cycles are discussed below. Chemical and physical data from process samples will be presented first followed by off-gas data.

\subsubsection{SME Cycle Slurry Samples}

Formate and nitrate loss are presented in Table 17 for samples taken of the SME product slurry. Formic acid was added with the frit-water slurry in all of these runs. 
Table 17. SME Anion Reactions

\begin{tabular}{|l|c|c|c|c|c|c|}
\hline Run ID: & 2M-100 & 2M-110 & 2M-125 & 2M-130 & 2.5M-100 & 2.5M130 \\
\hline Formate loss, \% & -3.1 & -11 & 6.5 & 9 & 1 & 6.7 \\
\hline Nitrate loss, \% & -10 & -16 & -1.1 & 5 & -2.9 & -1.2 \\
\hline
\end{tabular}

Negative formate losses are possible when the SME formate material balance indicates a gain in formate mass. Formate and nitrate losses between $-10 \%$ and $+10 \%$ cannot be significantly distinguished from zero due to propagated uncertainties in the material balances and analytical results.

SME product anion analytical data are given in Table 18 as $\mathrm{mg}$ anion/kg slurry. Oxalate is not reported due to issues with the analytical method.

Table 18. SME Product Anions, mg/kg

\begin{tabular}{|c|c|c|c|c|c|c|}
\hline Anions & 2M-100 & 2M-110 & 2M-125 & 2M-130 & 2.5M-100 & 2.5M130 \\
\hline $\mathrm{NO}_{2}{ }^{-}$ & 2,580 & $<500$ & $<500$ & $<500$ & 3,210 & $<500$ \\
\hline $\mathrm{NO}_{3}{ }^{-}$ & 22,350 & 23,150 & 23,050 & 22,800 & 20,900 & 22,600 \\
\hline $\mathrm{SO}_{4}{ }^{-}$ & 1,320 & 1,200 & 1,130 & 1,390 & 1,440 & 1,140 \\
\hline $\mathrm{HCO}_{2}{ }^{-}$ & 41,500 & 40,800 & 32,800 & 35,200 & 38,050 & 35,300 \\
\hline
\end{tabular}

Elemental wt.\% data for the six SME products after calcining at $1100{ }^{\circ} \mathrm{C}$ are given in Table 19.

Table 19. SME Calcined Elements at $1100{ }^{\circ} \mathrm{C}$-wt.\%

\begin{tabular}{|c|c|c|c|c|c|c|}
\hline Run ID & 2M-100 & 2M-110 & 2M-125 & 2M-130 & 2.5M-100 & 2.5M130 \\
\hline $\mathrm{Al}$ & 5.67 & 5.67 & 5.31 & 6.37 & 5.96 & 6.25 \\
\hline $\mathrm{B}$ & 1.58 & 1.65 & 1.55 & 1.31 & 1.65 & 1.32 \\
\hline $\mathrm{Ba}$ & 0.03 & 0.03 & 0.33 & 0.04 & 0.03 & 0.04 \\
\hline $\mathrm{Ca}$ & 0.21 & 0.21 & 0.21 & 0.32 & 0.19 & 0.28 \\
\hline $\mathrm{Cr}$ & 0.02 & 0.01 & 0.02 & 0.01 & 0.02 & 0.02 \\
\hline $\mathrm{Cu}$ & 0.02 & 0.03 & 0.02 & 0.01 & 0.02 & 0.01 \\
\hline $\mathrm{Fe}$ & 5.12 & 4.45 & 4.18 & 4.72 & 4.68 & 5.50 \\
\hline $\mathrm{K}$ & 0.16 & 0.16 & 0.15 & 0.20 & 0.18 & 0.18 \\
\hline $\mathrm{Li}$ & 2.10 & 2.16 & 1.99 & 2.15 & 2.12 & 2.19 \\
\hline $\mathrm{Mg}$ & 0.12 & 0.12 & 0.12 & 0.16 & 0.11 & 0.14 \\
\hline $\mathrm{Mn}$ & 1.76 & 1.65 & 1.59 & 1.51 & 1.61 & 1.71 \\
\hline $\mathrm{Na}$ & 12.1 & 12.1 & 11.7 & 12.5 & 12.7 & 12.4 \\
\hline $\mathrm{Ni}$ & 0.61 & 0.61 & 0.58 & 0.65 & 0.54 & 0.72 \\
\hline $\mathrm{S}$ & 0.09 & 0.08 & 0.08 & 0.12 & 0.11 & 0.10 \\
\hline $\mathrm{Si}$ & 24.9 & 25.2 & 23.9 & 24.0 & 25.0 & 24.0 \\
\hline $\mathrm{Ti}$ & 0.02 & 0.03 & 0.02 & 0.06 & 0.03 & 0.06 \\
\hline $\mathrm{Zn}$ & 0.02 & 0.02 & 0.02 & 0.02 & 0.02 & 0.02 \\
\hline $\mathrm{Zr}$ & 0.08 & 0.08 & 0.38 & 0.18 & 0.08 & 0.19 \\
\hline
\end{tabular}

SME product solids data, densities, and $\mathrm{pH}$ are given in Table 20. The SME targeted $45 \mathrm{wt} \%$ total solids. The wt.\% insoluble and soluble solids were calculated from the measured total slurry and supernate (dissolved) solids. The density measurements were made at $25^{\circ} \mathrm{C}$. 
Table 20. Additional SME Product Properties

\begin{tabular}{|l|c|c|c|c|c|c|}
\hline Run ID: & 2M-100 & 2M-110 & 2M-125 & 2M-130 & 2.5M-100 & 2.5M130 \\
\hline Wt. \% total solids & 45.3 & 45.0 & 45.1 & 45.8 & 46.0 & 44.3 \\
\hline Wt. \% insoluble solids & 35.5 & 35.0 & 36.2 & 36.5 & 36.6 & 34.3 \\
\hline Wt. \% soluble solids & 9.7 & 10.0 & 8.9 & 9.3 & 9.4 & 10.0 \\
\hline Wt. \% calcined solids & 38.3 & 38.1 & 38.1 & 37.2 & 38.7 & 36.1 \\
\hline Slurry density, g/mL & 1.361 & 1.364 & 1.328 & 1.345 & 1.373 & 1.333 \\
\hline Supernate density, g/mL & 1.101 & 1.102 & 1.092 & 1.092 & 1.105 & 1.097 \\
\hline Product pH at $25^{\circ} \mathrm{C}$ & 7.6 & 7.7 & 8.7 & 9.1 & 7.8 & 8.9 \\
\hline
\end{tabular}

\subsubsection{SME Off-gas Data}

SME cycle hydrogen generation rates are presented in Figure 6 . The red line at $0.223 \mathrm{lb} / \mathrm{h}$ on the y-axis represents the DWPF SME hydrogen limit.

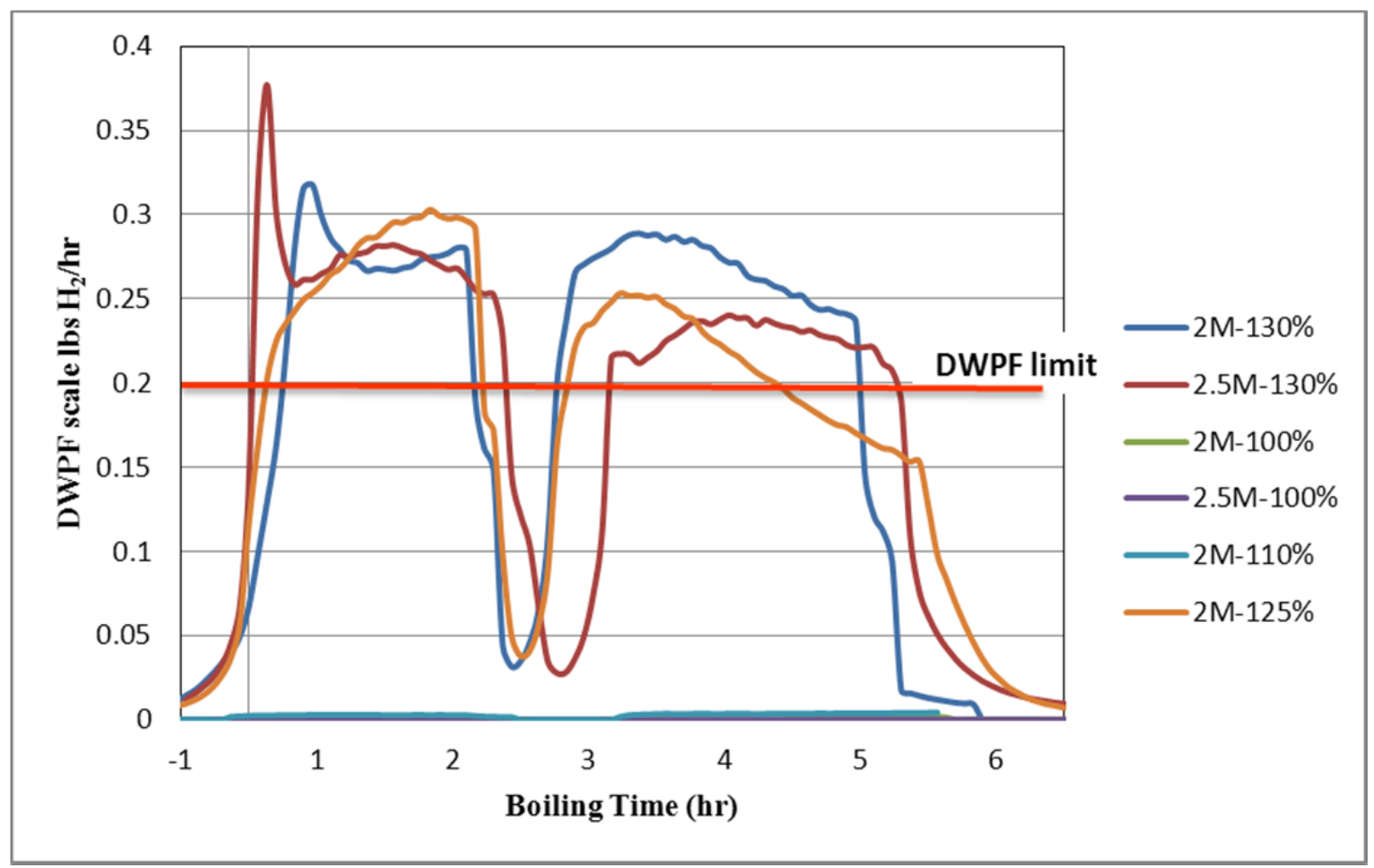

Figure 6. SME Cycle Hydrogen

For the three highest acid runs $(130 \%$ at $2 \mathrm{M}$ and $2.5 \mathrm{M}$, and $125 \%$ at $2 \mathrm{M})$, the formic acid in the frit slurry addition triggered hydrogen generation in the run that exceeded the DWPF SME limit. Little, if any, hydrogen was seen in the three low acid runs, although more was seen in the $110 \%$ run than in the $100 \%$ runs.

Carbon dioxide generation rates for the SME cycle are given in Figure 7. The spikes are associated with the onset of boiling following each of the two frit slurry additions. 


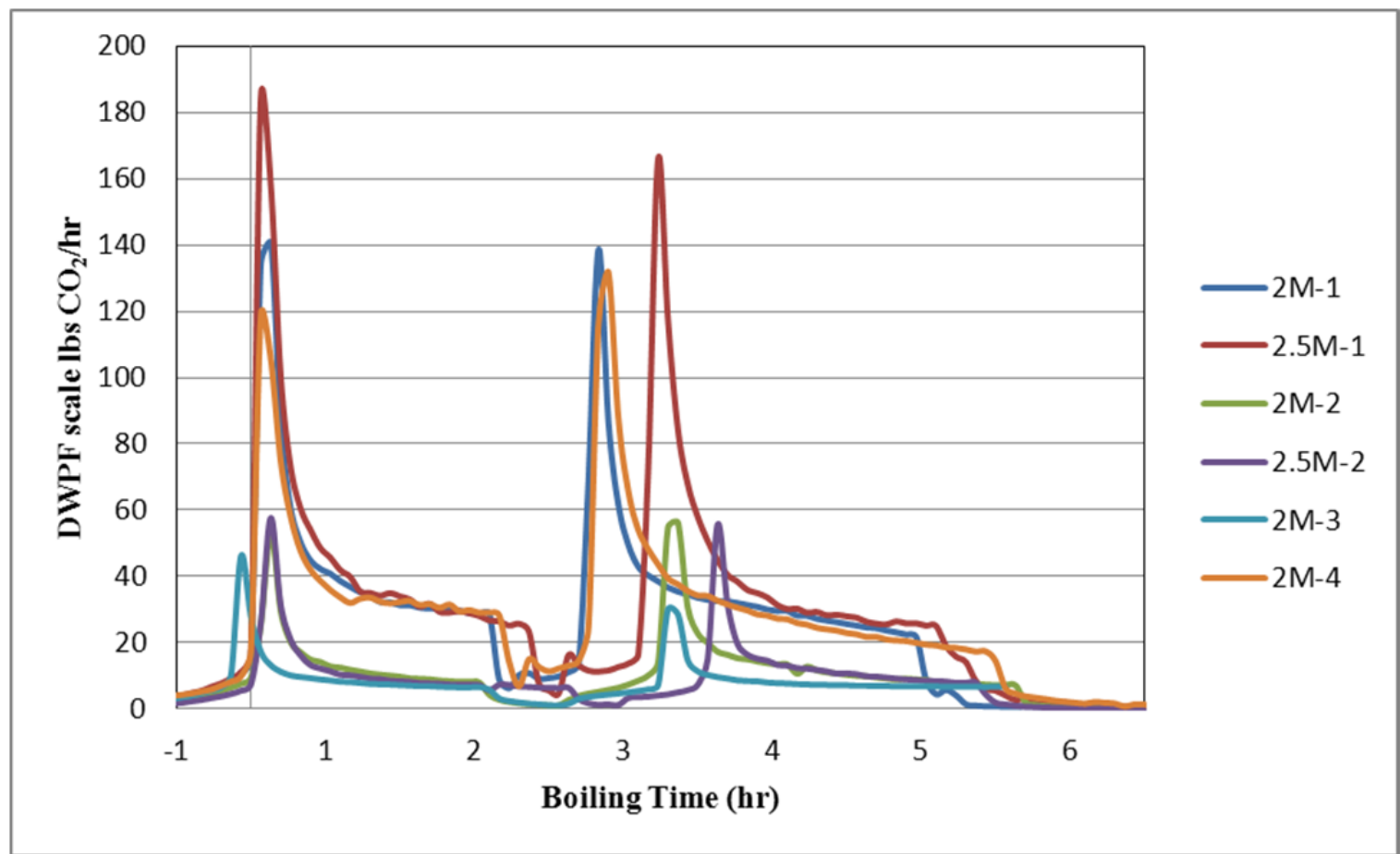

Figure 7. SME Cycle Carbon Dioxide

\subsection{Conclusions}

Scoping studies were completed for high sodium simulant SRAT/SME cycles to determine any impact to CPC processing. Two SRAT/SME cycles were performed with simulant having sodium supernate concentration of $1.9 \mathrm{M}$ at $130 \%$ and $100 \%$ of the Koopman Minimum Acid requirement. Both of these failed to meet DWPF processing objectives related to nitrite destruction and hydrogen generation. Another set of SRAT/SME cycles were performed with simulant having a sodium supernate concentration of $1.6 \mathrm{M}$ at $130 \%, 125 \%, 110 \%$, and $100 \%$ of the Koopman Minimum Acid requirement. Only the run at $110 \%$ met DWPF processing objectives. Neither simulant had a stoichiometric factor window of $30 \%$ between nitrite destruction and excessive hydrogen generation.

A summary of the test results is presented in Table 21.

Table 21. Summary of Scoping Study Results

\begin{tabular}{|c|c|c|}
\hline Run ID & Pass/Fail & Constraint \\
\hline $2 \mathrm{M}-100$ & Fail & Nitrite $(3800 \mathrm{mg} / \mathrm{kg})$ \\
\hline $2 \mathrm{M}-110$ & Pass & Nitrite $(620 \mathrm{mg} / \mathrm{kg})$ \\
\hline $2 \mathrm{M}-125$ & Fail & Hydrogen $(\mathrm{SME})$ \\
\hline $2 \mathrm{M}-130$ & Fail & Hydrogen $(\mathrm{SME})$ \\
\hline $2.5 \mathrm{M}-100$ & Fail & Nitrite $(4900 \mathrm{mg} / \mathrm{kg})$ \\
\hline $2.5 \mathrm{M}-130$ & Fail & Hydrogen $($ SRAT/SME) \\
\hline
\end{tabular}

Based on the $2 \mathrm{M}-110$ results it was anticipated that the $2.5 \mathrm{M}$ stoichiometric window for processing would likely be smaller than from $110-130 \%$, since it appeared that it would be 
necessary to increase the KMA factor by at least $10 \%$ above the minimum calculated requirement to achieve nitrite destruction due to the high oxalate content. The $2.5 \mathrm{M}-130$ run exceeded the DWPF hydrogen limits in both the SRAT and SME cycle. Therefore, testing of this wash endpoint was halted. This wash endpoint with this minimum acid requirement and mercury-noble metal concentration profile appears to be something DWPF should not process due to an overly narrow window of stoichiometry.

The 2M case was potentially processable in DWPF, but modifications would likely be needed in DWPF such as occasionally accepting SRAT batches with undestroyed nitrite for further acid addition and reprocessing, running near the bottom of the as yet ill-defined window of allowable stoichiometric factors, potentially extending the SRAT cycle to burn off unreacted formic acid before transferring to the SME cycle, and eliminating formic acid additions in the frit slurry.

\subsection{Path Forward}

The results presented in this report are valid only for the simulant and levels of noble metals tested. SB7 levels of noble metals and mercury were used for this scoping study and represent a maximum bounding scenario. SB8 levels of noble metals are projected to be slightly lower and SB8 mercury concentrations are projected to be slightly higher which could both mitigate some of the hydrogen generation. Recent projections for oxalate are only about half as large as those tested which such bring the minimum acid requirement for nitrite destruction closer to the value predicted by the KMA. SB8 also appears to be much higher in Fe/Al ratio than SB7a or SB7b, so the simulant tested in these studies is not a good match in terms of insoluble solids concentration to that expected for SB8.

It is recommended that these studies be repeated at the 2M Na wash endpoint in Tank 51 once updated composition projections for SB8 are received and the results used to produce more representative simulants. Testing should include both the Tank 40 and Tank 51 versions, in order to determine DWPF processability as well as the likelihood of having a successful qualification run in the Shielded Cells using a sample from Tank 51.

Although SB8 noble metals concentrations are expected to be lower than SB7, future sludge batches are likely to approach or exceed SB7 levels. It is recommended that alternative processing strategies to mitigate hydrogen generation be pursued such as the glycolic/nitric acid flowsheet.

\subsection{Acknowledgements}

The author acknowledges the assistance of Jon Duvall, Phyllis Workman, Vickie Williams, David Healy, Tony Burckhalter, Beverly Walls, and Doug Sumpter for their support during these around-the-clock runs.

Thank you to Jack Zamecnik for his calibration, operation, and post-run analysis of the FTIR and MS.

Thank you to Frances Williams and John Pareizs for their support of the GC calibration, analysis, and post-run processing.

Thank you to Whitney Riley, Beverly Walls, and David Best for their sample analyses.

Thank you to David Koopman, Mike Stone, Dan Lambert, and Connie Herman for their technical reviews and support. 


\subsection{References}

${ }^{1}$ C.C. Herman, D.C. Koopman, D.R. Best, T.K. Snyder, M.F. Williams, "Sludge Batch 3 Simulant Flowsheet Studies: Final Phase SRAT/SME Results," WSRC-TR-2003-00422, September 2003.

${ }^{2}$ D.K. Peeler, T.B. Edwards, "Measurement Acceptability Region (MAR) Assessments for the June 2012 SB8 Projections,” SRNL-L3100-2012-00125, September 2012.

${ }^{3}$ J.M. Gillam, D.W. McIlmoyle, "Sludge Batch Plan in Support of System Plan Rev.17," SRRLWP-2011-00067, January 2012.

${ }^{4}$ T.B. Edwards, J.R. Harbour, "Sensitivity of Acid Addition Strategy to Input Uncertainties at DWPF for SB3,” SRT-SCS-2003-00027, June 19, 2003.

${ }^{5}$ T.B. Edwards, J.R. Harbour, “A preliminary Assessment of the Sensitivity of the Shielded Cells' Acid Addition Strategy to Measurement Uncertainties,” SRTC-SCS-2003-00031, July 23, 2003.

${ }^{6}$ D.C. Koopman, C.M. Jantzen, T.B. Edwards, “Acid Addition Stoichiometry for Sludge Batch 3 Processing in the Defense Waste Processing Facility,” WSRC-TR-2003-00118, February 27, 2003.

${ }^{7}$ J.M. Bricker, “Sludge Batch 8 Flowsheet Studies,” HLW-DWPF-TTR-2012-0004, November 2011.

${ }^{8}$ J.D. Newell, "Task Technical and Quality Assurance Plan for Sludge Batch 8 Simulant Flowsheet Studies,” SRNL-RP-2011-01679, December 2011.

${ }^{9}$ D.C. Koopman, "Noble Metal Chemistry and Hydrogen Generation during Simulated DWPF Melter Feed Preparation,” WSRC-STI-2008-00002, June 2008.

${ }^{10}$ J.D. Newell, “Simulant Development for Sludge Batch 6,” SRNL-STI-2010-00219, April 2010.

${ }^{11}$ M.E. Stone, “Lab-scale CPC Equipment Setup,” SRNL-L3100-2011-00127, July 2011.

${ }^{12}$ D.C. Koopman, A.I. Fernandez, B.R. Pickenheim, "Preliminary Evaluations of Two Proposed Stoichiometric Acid Equations,” SRNL-L3100-2009-00146, 2009.

${ }^{13}$ J.C. Marek, R.E. Eibling, "Calculational Algorithms for Nitric Acid Sludge Adjustment," SRTC-PTD-92-0050, September 1992.

${ }^{14}$ C.M Jantzen, M.E. Stone, "Role of Manganese Reduction/Oxidation (RedOx) on Foaming and Melt Rate in High Level Waste Melters,” WSRC-STI-2006-00066, March 2007.

${ }^{15}$ SRNL L29 Manual, Procedure ITS-0094, Rev. 4, "Laboratory Scale Chemical Process Cell Simulations," SRNL, Aiken, SC, 29808. 


\section{Distribution:}

J.W. Amoroso, 999-W

D.R. Best, 999-W

H.P. Boyd, 704-27S

J.M. Bricker, 704-27S

T.B. Edwards, 999-W

T.L. Fellinger, 704-26S

S.D. Fink, 773-A

K.M. Fox, 999-W

J.M. Gillam, 766-H

C.C. Herman, 999-W

E.W. Holtzscheiter, 704-15S

J.F. Iaukea, 704-30S

P.R. Jackson, 703-46A

C.M. Jantzen, 773-A

F.C. Johnson, 999-W

M.T. Keefer, 241-156H

D.C. Koopman, 999-W
D.P. Lambert, 999-W

S.L. Marra, 773-A

D.W. McIlmoyle, 766-H

J.D. Newell, 999-W

J.E. Occhipinti, 704-S

J.M. Pareizs, 773-A

D.K. Peeler, 999-W

F.M. Pennebaker, 773-42A

J.W. Ray, 704-S

W.T. Riley, 999-W

H.B. Shah, 766-H

D.C. Sherburne, 704-S

A.V. Staub, 704-27S

M.E. Stone, 999-W

K.H. Subramanian, 766-H

J.R. Zamecnik, 999-W 